
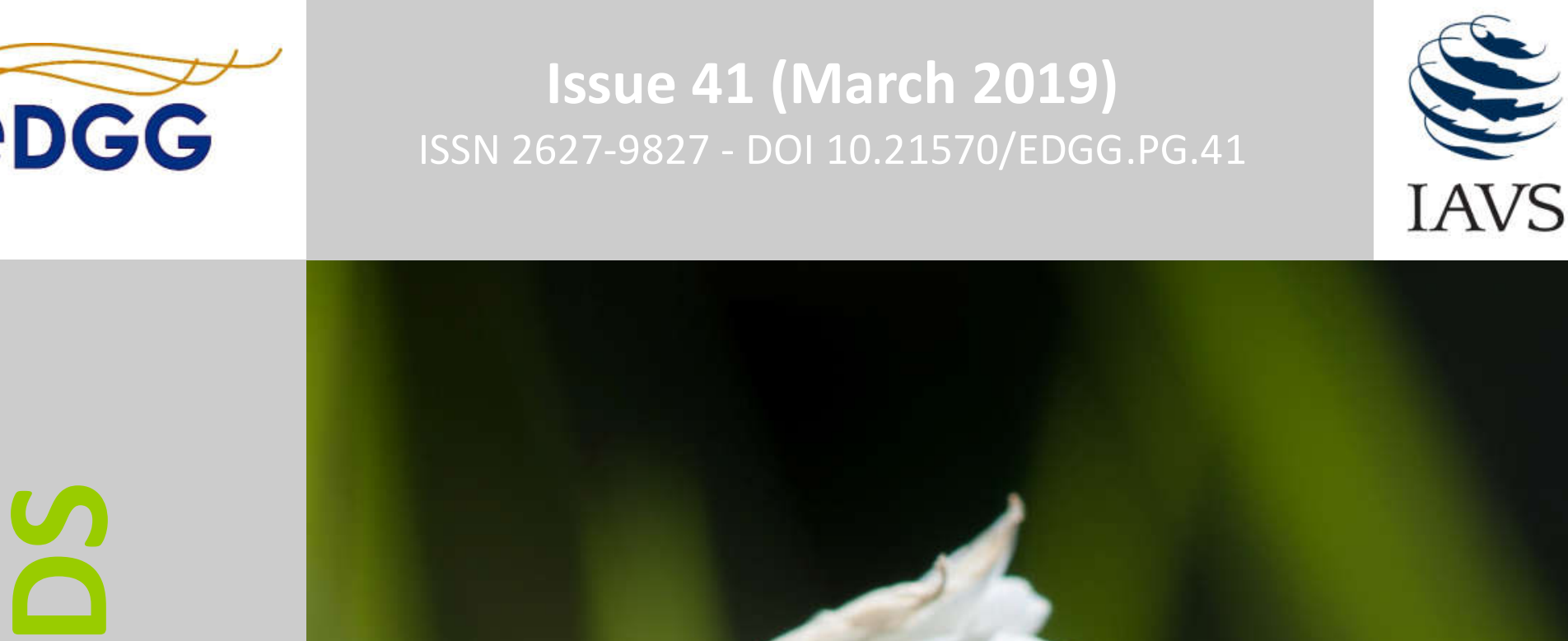

$+$

(2)

\%

2

U

4

$\mathrm{P}^{2}$

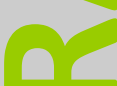

$\frac{10}{2}$

0
8

(1)

要

(U) $\frac{\frac{1}{6}}{\frac{\pi}{4}}$

U

更

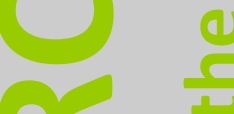

a

$1 \frac{4}{0}$

4 तु

달

$<\frac{2}{3}$

$-1$

2 


\section{Table of Contents}

Editorial

Election to the Executive Committee of the EDGG 2019-2021

Photo Story, Photo Competition and Grassland Art Competition

EDGG Field Workshops 2019the international research expeditions to study grassland diversity across multiple scales and taxa: Call for participation

$62^{\text {nd }}$ Annual Symposium of the IAVS "Vegetation Science and Biodiversity Research", 14-19 July 2019, Bremen

Vasyliuk et al. Fire in the protected areas of Eastern Ukraine

Recent Publications of our Members

Forthcoming Events

About EDGG

Palaearctic Grasslands

ISSN 2627-9827

DOI 10.21570/EDGG.PG41

Palaearctic Grasslands, formerly published under the names Bulletin of the European Dry Grassland Group (Issues 1-26) and Bulletin of the Eurasian Dry Grassland Group (Issues 27-36) is the journal of the Eurasian Dry Grassland Group (EDGG). It usually appears in four issues per year. Palaearctic Grasslands publishes news and announcements of EDGG, its projects, related organisations and its members. At the same time it serves as outlet for scientific articles and photo contributions.

Palaearctic Grasslands is sent to all EDGG members and, together with all previous issues, it is also freely available at http://www.edgg.org/publications.htm.

The copyright of the included texts, photographs, and other figures remains with their authors. If you wish to re-use them or parts of them, please, obtain the written consent of the authors first.

Scientific articles (Research Articles, Reviews, Forum Articles, Scientific Reports) should be submitted to Jürgen Dengler (juergen.dengler@uni-bayreuth.de), following the Author Guidelines published in Palaearctic Grasslands 37, 6-8. They are subject to editorial review, with one member of the Editorial Board serving as Scientific Editor and deciding about acceptance, necessary revisions or rejection.

All other text contributions (News, Announcements, Short Contributions, Book Reviews,...) should be submitted to Anna Kuzemko (anyameadow.ak@gmail.com) AND Idoia Biurrun (idoia.biurrun@ehu.es). Please check a current issue of Palaearctic Grasslands for the format and style. Deadline for submission to the next issue is 20 April 2019

Photo and art contributions (for general illustrative purposes with captions; proposals for Photo Stories; contributions to Photo and Art Competition) should be submitted to both Photo Editors, Rocco Labadessa (rocco.labadessa@gmail.com) AND Jalil Noroozi (noroozi.jalil@gmail.com). Deadline for submissions to the next Photo Competition on "Grassland close-up" and Art Competition is 20 April 2019.

Contributions to the sections "Recent Publications of our Members" and "Forthcoming Events" should be sent to Iwona Dembicz (iwodem@op.pl).

Photos included in submissions have always to be delivered in two forms, embedded in the document and as separate jpg (or tiff) files with sufficient resolution for printing (i.e. not less than $1 \mathrm{MB}$ ).

Palaearctic Grasslands is published by EDGG c/o Prof. Dr. Jürgen Dengler, Plant Ecology, BayCEER, University of Bayreuth, Universitätsstr. 30, 85447 Bayreuth, Germany.

\section{Editorial Board}

CHIEF EDITOR:

Anna Kuzemko, Ukraine

DEPUTY CHIEF EDITORS:

Idoia Biurrun, Spain

Jürgen Dengler, Switzerland

\section{EDITORAL BOARD:}

Dolores Byrne, Ireland

Iwona Dembicz, Poland

Edy Fantinato, Italy

Magdalena Firganek-Fulcher, UK

Paul Goriup, UK

Riccardo Guarino, Italy

Richard Jefferson, UK

Gwyn Jones, UK

Rocco Labadessa, Italy
Frank Yonghong Li, China

Ashley Lyons, UK Lorna Marcham, UK Jim Martin, Ireland James Moran, Ireland Jalil Noroozi, Austria Arkadiusz Nowak, Poland Salza Palpurina, Bulgaria Nina Polchaninova, Ukraine

Solvita Rūsina, Latvia

Stuart Smith, UK Laura Sutcliffe, Germany Péter Török, Hungary Atushi Ushimaru, Japan Orsolya Valkó, Hungary Stephen Venn, Finland 


\section{Editorial}

Dear readers,

You might be surprised to receive Palaearctic Grasslands No. 41 so shortly after issue No. 40. The main reason is that this issue contains two urgent announcements that had to be published without delay. Shortly after the distribution of this issue, the EDGG members will be invited to elect the new Executive Committee for the period 2019-2021 during a 14-day election period. On pages $4-7$, the eleven candidates for the seven seats present themselves. Moreover, we are excited to announce that this year there will be two attractive Field Workshops to study multi-scale and multi-taxon biodiversity patterns in grasslands, one in the inneralpine dry valleys of Switzerland and the other along the elevational gradient in Armenia (pp. 9-22). Please be aware that there is a short deadline for registration as well as travel grant application (31 March). We would also like to highlight this year's international symposium of our parental organisation IAVS in Bremen, where there are, apart from many other exciting things, two special sessions organised by us and excursions with a clear grassland focus (pp. 23-25).

While it is not our plan to publish Palaearctic Grasslands now in monthly interval, the good news is that the new concept of the journal attracts so many more submissions than in the past that we believe that likely we can achieve a regular publication interval of approx. 2-3 months. This makes it easier for you to submit small items in time for the next issue, while scientific articles after acceptance will not have to wait too long in the queue before a "slot" in a Palaearctic Grassland issue becomes available.

Last but not least, we editors have decided to launch another new feature with this issue: the Grassland Art Competition, which complements our Photo Competition and is organised by the same two editors, Rocco Labadessa and Jalil Noroozi. We hope that this will attract many beautiful paintings and drawings. Moreover, due to low number of submissions in consequence of the very short deadline, we have decided to extend the deadline for the current Photo Competition on "Grassland close-up" to 20 April (further details on p. 8).

Enjoy reading and the upcoming spring in your favourite grasslands,

Jürgen Dengler, Deputy Chief Editor juergen.dengler@uni-bayreuth.de

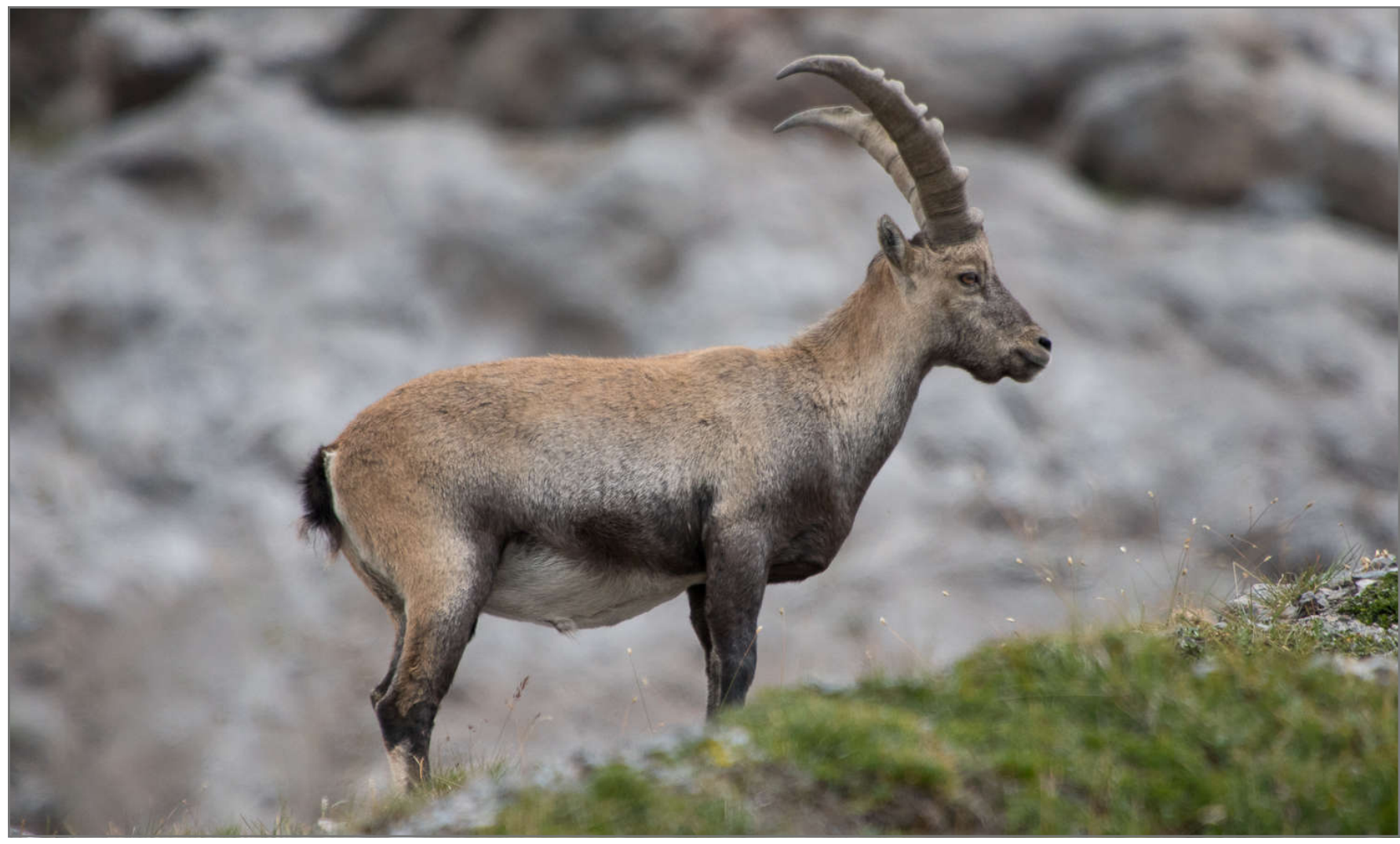




\section{News}

\section{Election to the Executive Committee of the EDGG 2019-2021}

We hereby announce the 2019 election for the Executive Committee of the EDGG. The election will be conducted by an electronic ballot. According to the terms of the EDGG Bylaws, the Executive Committee comprises seven chairs, who serve terms of two years, beginning at the time of the General Assembly. There are 11 candidates for the election and each member is entitled to vote for up to seven candidates. The seven candidates with the highest number of votes will be elected. In the case of a tie for the seventh position, all candidates with the same number of votes will

\section{Alla Aleksanyan (Armenia)}

I am a young scientist from Armenia. I'm interested in the different aspects of investigation of ecosystems, mainly grasslands in high mountainous countries (for example biodiversity, habitat classification, conservation, impact assessment etc.). Since 2015, I have been an active member of IAVS, and since 2016 a member of EDGG. From

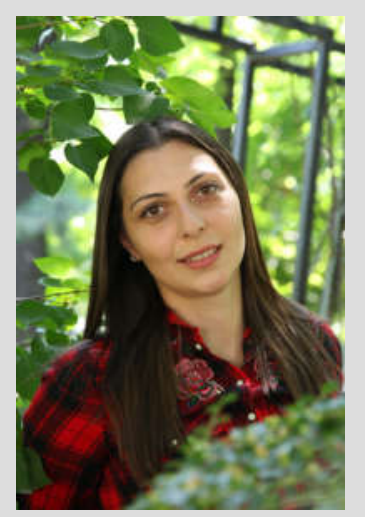

2016-2018, I was a member of the IAVS Young Scientist Council. The EDGG is a great platform for sharing experience, networking and for starting new international fruitful collaborations. I represent one of the world hotspots of biodiversity i.e. the Caucasus, where there is a unique diversity of grasslands. I'm trying to attract more attention to this hotspot and not very well explored part of the world from the point of view of ecosystems and biodiversity. If I will be elected as one of the Executive Committee Members, I will put all my efforts into increasing awareness-raising about the EDGG and involving more members, especially from the countries which are not represented now or have significance for grassland research, and I will try to start an interdisciplinary joint project on grasslands and of course I will support all the activities and initiatives of the EDGG. be elected. In order to improve geographic representativeness, the one member based in Europe (in a physicalgeographical sense) and the one based outside Europe with the highest number of votes shall be elected, even if they are not among the seven with the overall highest number of votes. Invitations will be sent out to all members of the EDGG shortly.

Here are short biosketches of the 11 candidates standing for election, to help you choose up to seven to vote for:

\section{Didem Ambarli (Germany/Turkey)}

I am an assistant professor at Duzce University, Turkey and currently a postdoc at the Technical University of Munich, Germany. My research focuses on community ecology and conservation science. My research subjects include distribution patterns and community composition in grasslands,

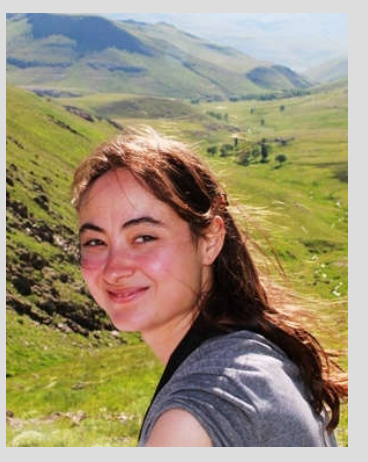
successional dynamics, ecosystem processes, conservation planning and vegetation classification. I have been a member of EDGG and Med-EDGG since 2011. I see the EDGG as a crucial organization in mainstreaming advances in grassland research and conservation. I have been a chair in the EDGG for two terms. I am responsible for the website management and conference organization. I was actively involved in organizing the Sighişoara, Riga, Sulmona and now Graz conferences. I built the new EDGG website, with the help of a website administrator. In the next term, I would like to continue improving the EDGG website, with new pages and functionalities and organizing excellent conferences. Furthermore, I'd like to increase the recognisability of the EDGG and improve the membership from underrepresented countries, as well as promoting interdisciplinary work, especially with social science dimensions. These are among the things I'd like to do for the EDGG. 


\section{Idoia Biurrun (Spain)}

I am an associate professor at the University of the Basque Country in Bilbao, Spain. My interest as a vegetation scientist is focused on the classification, ecology and diversity patterns of grasslands and other habitats as forests, rivers and mires. have been an active member of the EDGG

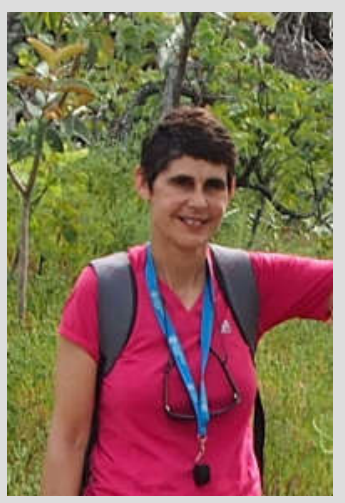
since 2012 and the last

four years I have participated in the Executive Committee as Membership Administrator, deputy Chief Editor of our journal, Palaearctic Grasslands (formerly Bulletin of the Eurasian Dry Grassland Group) and deputy Field Workshop Coordinator. In 2014, I organized the $7^{\text {th }}$ Field Workshop in Navarre (Spain) and I am Deputy Custodian and Manager of the EDGG-affiliated GrassPlot database since 2017. I have also been involved as editor of several EDGG Special Features in the journal Hacquetia. I would like to continue my contribution to the development of the EDGG. Specifically, I would like to help in attracting more scientists and nature managers from countries that are currently poorly represented in the EDGG to participate in EDGG events, such as conferences and field workshops, to submit research papers to Palaearctic Grasslands and to contribute their data to GrassPlot.

\section{Iwona Dembicz (Poland)}

I am a research associate at the Polish Academy of Sciences. In parallel I am finishing my $\mathrm{PhD}$ thesis at the University of Warsaw. My scientific interests include ecology and biodiversity patterns of grassland ecosystems and the impact of habitat fragmentation on grasslands. Moreover, I am active in

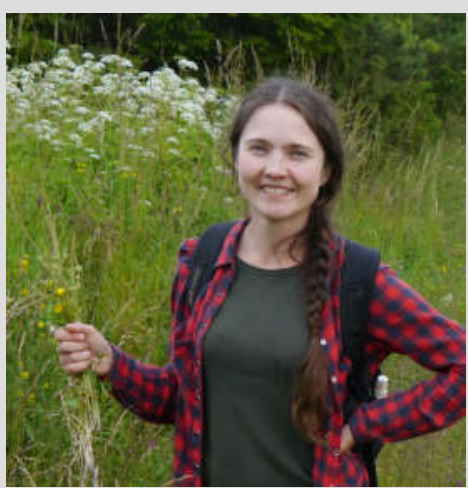
the fields of nature con-

servation and ecological restoration. I have been a member of the EDGG since 2011. I participated in seven EDGG Research Expeditions/Field Workshops and three annual meetings. Since 2017, I have been involved in the development of the GrassPlot database, which is a collaborative activity within the EDGG. Besides this, for nearly one year I have been a member of the editorial board of the journal Palaearctic Grasslands. I think that the EDGG is a fantastic network created by and for researchers and conservationists. Nowadays, effective protection of grasslands is a challenge, so it is important to document their diversity and beauty, conduct studies, exchange experiences and ideas, and cooperate over political and financial obstacles. In my opinion, the EDGG facilitates these tasks and as a member of the Executive Committee, I would like to contribute to its further development through continuing my current activities and supporting organizational issues connected with Field Workshops, annual conferences and the website.

\section{Jürgen Dengler (Switzerland/Germany)}

I am Professor of Vegetation Ecology at the Zurich University of Applied Sciences (ZHAW), Switzerland and "Privatdozent" at the University of Bayreuth, Germany. My research interests cover plant community ecology, vegetation classification, biodiversity analyses, macroecology, ecoinformatics and conservation biology in many different habitats and regions, but with a focus on Palaearctic semi-natural and natural grasslands. I am member of the IAVS Council and Chair of the IAVS Membership Committee, Chief Editor of Phytocoenologia and Editorial Board member of Applied Vegetation Science. In the EDGG, I am the last remaining "veteran" from the three founding chairs, back in 2008, and ever since have served in the Executive Committee. In this capacity, I have organised numerous Special Features in international journals and recently the Palaearctic chapters in the global grassland book, initiated and coordinated the annual Field Workshops, founded GrassPlot and several regional EDGG-associated vegetation-plot databases.

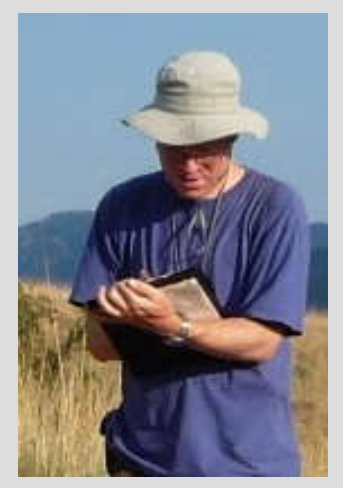
In 2018, I was pivotal in the transition from the EDGG Bulletin to Palaearctic Grasslands as a new type of peer-reviewed scientific journal and since then have serve as Deputy Chief Editor. In the future, I hope that the EDGG will remain the network of enthusiastic grassland specialists who jointly move things forward. While I am prepared to take on any role required in the next Executive Committee if elected, I see my major roles in gaining more active members from Asian and African countries, as well as zoologists, and in translating the increasing treasure of high-quality data from more than one decade of Field Workshops via GrassPlot, into impactful publications. And perhaps the time is now also ripe for the EDGG to start the preparation of a multi-volume book series on the ecology, biodiversity and conservation of Palaearctic grasslands; this is my long-term dream. 


\section{Anna Kuzemko (Ukraine)}

I am the Leading Researcher of the Geobotany and Ecology Department at the M.G. Kholodny Institute of Botany NAS of Ukraine, and Doctor of Biological Science. My scientific interests are grassland vegetation - its classification, ecology, dynamics, management and conservation. In recent years, I have been

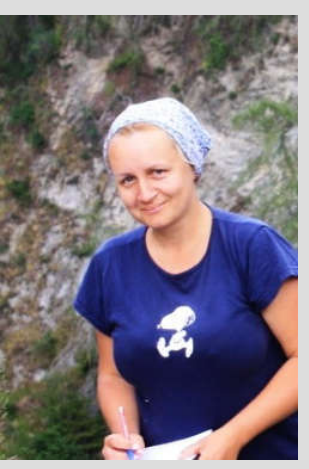
deeply involved in the devel-

opment of the Emerald Network and the implementation of the Habitat Directive in Ukraine. I have been a member of the EDGG since 2008. I organized the 2nd EDGG Expedition in Central Podolia (Ukraine) in 2010 and the 8th EDGG Meeting in Uman' (Ukraine) in 2011. I hope to help the EDGG to involve scientists from the post-soviet countries in the various activities of the EDGG. I have been a member of the EDGG Executive Committee since 2015. My responsibilities in the current EC are: Chief Editor of Palaearctic Grasslands and Social Media Administrator.

\section{Rocco Labadessa (Italy)}

I am an environmental biologist living in Italy, now working as a freelance consultant and independent researcher, focused on many ecological and zoological studies. Since I accidentally learned about the EDGG, I have loved the way in which so many different disciplines can be united through a common interest and cooperate towards transnational goals. So far, I have been involved as invited editor in some of EDGG's Special Features and I am very glad to be part of the Editorial Board of our journal Palaearctic Grasslands, with major tasks as Photo Editor. It is not only my own opinion that EDGG is a growing fact, considering both the width of its spatial coverage and its ability to involve different kinds of members, which is mostly due to the passion and reliability of former and current Executive Committees. For the coming years, I am motivated to cooperate within the EC in order to keep on driving the ongoing processes and to improve our ability to implement forthcoming opportunities.

\section{Frank Yonghong Li (China)}

I am a Professor of Ecology and head of the State Key Laboratory of Grassland Ecology at Inner Mongolia University (Hohhot, China). I am a member of the executive committee of the Grassland Society and the Ecological Society of China, and deputy editor-in -chief of the Journal of Arid Land. I have been working on grasslands since my student time at Montpellier University (France), and later at the Institute of Botany of the Chinese

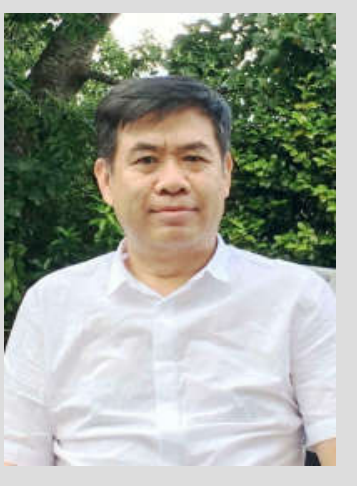
Academy of Sciences (Beijing) and at the New Zealand Institute for Pastoral Agriculture (Palm. North), before moving to my current position. My research covers biodiversity and ecosystem conservation, ecosystem functioning and services, and anthropogenic and climate change impacts on, and adaptive management of, grasslands, with a current focus on the steppes of the Mongolian Plateau. I have been an EDGG member for years, but mainly participated in the activities of the IAVS meetings. I am pleased to see the expansion of the EDGG from 'European' to 'Eurasian' and the initiation of Palaearctic Grasslands journal in recent years. I am looking forward to contributing to the further development of the EDGG, especially regarding the increase of EDGG activities in Asia and the visibility of Asian grasslands in EDGG publications.

\begin{abstract}
9. Salza Palpurina (Bulgaria)
I currently work as a researcher at the Bulgarian Academy of Science. I obtained my $\mathrm{PhD}$ in 2017 at Masaryk University (Czech Republic), where I studied finescale biodiversityenvironment relationships in dry grasslands. I joined the EDGG in 2011 and since then I have attended two of the EDGG Field Workshops. I am also an active member of the editorial team of Palaearctic Grasslands, the electronic journal of the EDGG. I believe that cooperation and sharing of knowledge and skills are the key to good quality research. Therefore, as a member of the executive committee of the EDGG, I will be happy to contribute to the ongoing efficient coordination and communication of research ideas and methods among members of EDGG, the collection of standardized data and to the enlargement of the current network.
\end{abstract}




\section{Péter Török (Hungary)}

My research interest cover conservation, and the conservation and biodiversity dynamics of grasslands. I work as an associate professor at the Department of Ecology, University of Debrecen, Hungary. Currently, I am also leading a scientific research group funded by the Hungarian Academy of Sciences, and I am co-author of 70 ISI papers, which have received more than 2,400 citations so far. I

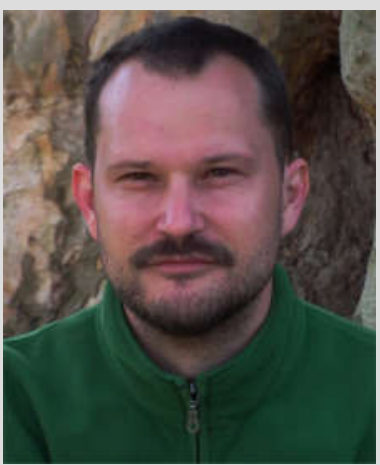

have been a chair of the EDGG since 2011. My current responsibilities within the EDGG are: IAVS Representative, Treasurer, Deputy Coordinator of Species Features, and Deputy SecretaryGeneral. I am a member of the editorial board of Palaearctic Grasslands and Book Review Editor. I acted as a guest editor in several EDDG organised special features. Together with the other chairs, we have built up good work contacts with other organisations working for grassland biodiversity. In the case of my re-election to the EC, I will help to strengthen the current policy work of the EDGG and to facilitate its communication with other conservation and restoration organisations. As a chair, I will work to facilitate the participation of young vegetation scientist and colleagues at EDGG events, especially at the Eurasian Grassland Conferences, and to support the recognition of grassland conservation and restoration work in Eurasia.

\section{Stephen Venn (Finland/UK)}

I am Adjunct Professor in Ecology at the University of $\mathrm{Hel}$ sinki, Finland, and I am specialized in Urban Ecology. I am also strongly interested in questions of sustainability, and I am affiliated to the Helsinki Institute of Sustainability Science (HELSUS) and

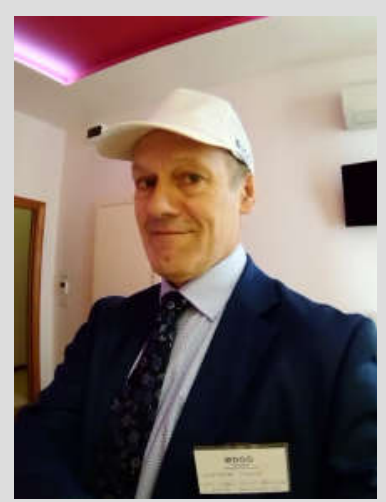
Helsinki Institute of Urban and Regional Studies (Urbaria). My empirical research focuses on plant-insect assemblages of meadow habitats; I am most familiar with carabid beetles, though also work with bees, butterflies and spiders. I have been a member of the EDGG since 2010 and member of the Executive Committee since 2011, currently in the role of Secretary-General. I am also a member of the editorial committee of Palaearctic Grasslands and have contributed to the editing of three Hacquetia Special Features for the EDGG. If I am re-elected to the EC I will be particularly interested to participate in initiatives to enhance research collaboration within EDGG.

\section{New Editorial Board Member}

The expansion of our Editorial Board is still ongoing. We are pleased to introduce our new scientific editor and the first from the big grassland country China - Frank Yonghong Li - and his vision of the development of Palaearctic Grasslands.

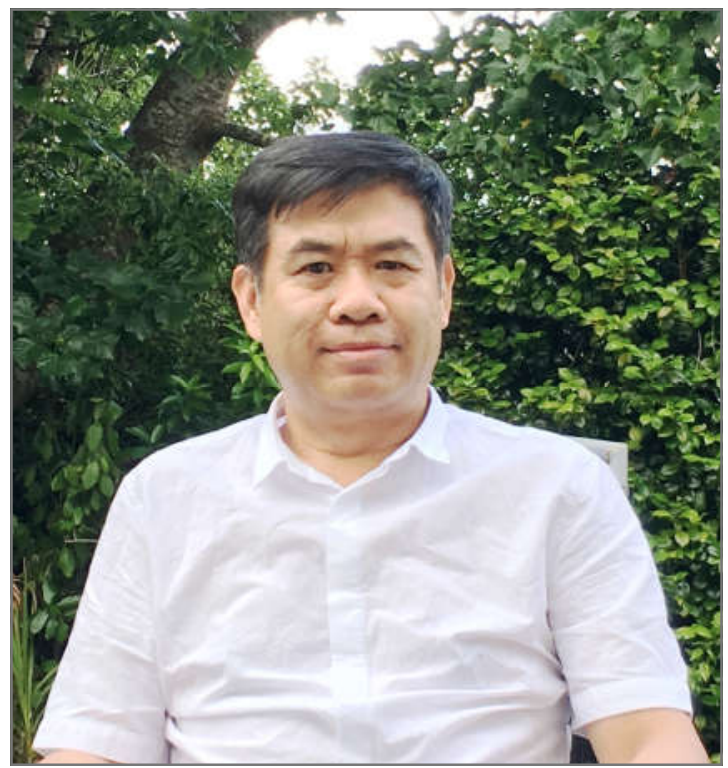

It is great to see the initiative of Palaearctic Grasslands following the expansion of the EDGG from 'European' to 'Eurasian' in recent years. I vision the journal as a living forum for grassland scientists, practitioners and amateurs to exchange ideas, discuss problems, share experiences, and promote activities in the research, conservation and management of Palaearctic Grasslands. I very much look forward to contributing to its development, especially to the increase of the journal's visibility in Asia and the visibility of Asian grasslands in the journal.

Frank Yonghong Li Professor of Ecology Dean, School of Ecology and Environment Inner Mongolia University, China lifyhong@126.com 


\section{Photo Story, Photo Competition and Grassland Art Competition}

In this issue, in addition to the sections "Photo Story" and "Photo Competition", we are pleased to launch a new section devoted to the beauty of Palaearctic grasslands: "Grassland Art Competition"!

Grassland Art Competition is a new call for grassland artists, who can challenge each other on a predefined grassland theme. Every kind of drawings or paintings are welcome, with no restrictions regarding realization technique. For the first call of the EDGG Art Competition, with the intention of starting an exploratory journey in the artistic works of EDGG people, we propose the wide theme "Grassland subjects". With this theme we are looking for all drawings or paintings regarding grasslands, considering landscapes or details from any point of view. If you want to contribute, you are invited to send up to three high-quality images within the competition theme (full size JPEG or TIFF images, at least $300 \mathrm{dpi}$ ) together with descriptions giving information on the title and the technique used.

The call for the Photo Competition is once again dedicated to the theme "Grassland close-up", focused on the surprising beauty and complexity of the smaller grassland details. The submission deadline for this theme, which was announced in the previous issue, has been extended till next issue in order to give you more time to participate. You are invited to send up to three high-quality photographs within the competition theme (full size JPEG or TIFF images, at least $300 \mathrm{dpi}$ ) together with captions giving information on the subject (species name, date, place name) and, possibly, technical details (camera, lens, aperture and exposure time).

For both Photo and Art Competitions, the selection will be made by a jury of at least five members from the Editorial Board of the journal. The three best works will be awarded with full space in the next issue, but we reserve the right to use further submitted materials for illustrative purposes in other parts of the issue.

If you feel you can contribute with your shots and/or your artwork, don't be shy! Everyone can join the competitions! Contributions for the Photo Story section are always welcome. Photo Story is an open space where members can submit their own photo collection on a certain grasslandrelated topic of their choice. High-quality photos should be provided together with their captions (at least species names or landscape description), a brief text and possibly other graphical elements (like a map or a drawing). The selection of photos should fit for 1-4 pages and the proponents should already propose a preliminary layout (in PDF or MS Word format), which will be finally typeset by Editors. As an example, you may take a look at the Photo Stories published in previous $P G$ issues.

If you want to contribute to these sections, or if you simply want to help us enriching the aspect of the journal, please submit your photos or artwork together with required information to Rocco (rocco.labadessa@gmail.com) and Jalil (noroozi.jalil@gmail.com).

Deadline for submissions to the next competitions is $\mathbf{2 0}$ April 2019! 


\section{EDGG Field Workshops 2019 - the international re- search expeditions to study grassland diversity across multiple scales and taxa: Call for participation}

\begin{abstract}
General Information
Background

Since 2009 (Dengler et al. 2009; Turtureanu et al. 2014) the Field Workshops (formerly: Research Expeditions) are one of the major annual activities of EDGG. They aim to sample Palaearctic grasslands across multiple scales (0.0001-100 $\mathrm{m}^{2}$ ) and multiple taxa (vascular plants, bryophytes and lichens) to generate standardised high-quality biodiversity data, together with in situ environmental and structural data. The method of data sampling, first proposed by Dengler (2009), has been revised and improved from year to year and has been recently described in detail (Dengler et al. 2016b). Together with the generation of high-quality datasets, the exchange of knowledge between participants from different countries and with diverse scientific interests and backgrounds is an important aim of the EDGG Field Workshops.
\end{abstract}

Data collected in these expeditions have already been used for a series of regional studies on phytosociological classification (Dengler et al. 2012; Pedashenko et al. 2013; Kuzemko et al. 2014), patterns and drivers of plant diversity (Turtureanu et al. 2014; Kuzemko et al. 2016; Polyakova et al. 2016). Data have also been used for a comparative overview on mean and maximum richness values of Palaearctic grasslands (Dengler et al. 2016a). Recently, various animal taxa including spiders (Polchaninova et al. 2018), grasshoppers (see Dengler et al. 2016b) and leafhoppers (Filibeck et al. 2018) have also been collected on the same plots to allow multi-taxon studies beyond the original three groups (vascular plants, bryophytes, lichens).

The multi-scale vegetation plot data from EDGG Field Workshops are fed into the "GrassPlot" database of EDGG (Dengler et al. 2018; http://bit.ly/2qKTQt2) to facilitate broader scientific utilization. This database is becoming a major source for macroecological studies, for example, on species-area relationships, alpha diversity, beta diversity or assembly rules. Finally, the Field Workshop data are also provided to national vegetation-plot databases, the European Vegetation Archive (EVA; Chytrý et al. 2016) and the global database "sPlot" (Bruelheide et al. 2019) to make them as useful as possible.

\section{Applications}

In general only EDGG members can participate in EDGG Field Workshops, but if non-members apply this will be considered as an application for free membership of the EDGG. Any application for participation or travel grants must be sent both to the Field Workshop Coordinator Jürgen Dengler (juergen.dengler@uni-bayreuth.de) and the respective local contact person (see below). Deadline for applications for both events in 2019 is the $31^{\text {st }}$ of March 2019. Confirmation of participation and feedback on travel grant applications will be given as soon as possible after this deadline, likely around the $10^{\text {th }}$ of April.

All applicants except those who already participated in four or more Field Workshops have to submit a motivation letter (10 lines maximum), explaining why they are interested in participation and what they would contribute to the success during and after the Field Workshop. High priority will be given to applicants who are competent in bryophyte or lichen determination or who are willing to carry out the soil analyses afterwards. Experts of non-plant taxa, such as grasshoppers, leaf hoppers, spiders, butterflies, fungi or soil metagenomics are also welcome to join if they are able and willing to carry out their sampling in a way that allows joint analyses with the vegetation biodiversity data. Such applicants are requested to discuss a potential sampling design prior to application with Jürgen Dengler and Idoia Biurrun and to clarify with the local organiser whether there are any legal constraints. The motivation letter is the most important criterion if there are more applications for participation than places, or for travel grants than money available.

If you apply for participation, please include in your e-mail apart from the motivation letter the following information:

- Name

- Age

- Professional status (e.g. PhD Student, Postdoc, Professor, Unemployed)

- Affiliation

- Address

- Mobile phone (we need to be able to contact you, e.g. when you get lost in the field) 
- Dietary requirements (no/vegetarian/other: please specify)

- If you are not an EDGG member yet, you need to agree explicitly to join EDGG (for free)

Travel grant application (Yes/No)

\section{Travel grants}

Regular travel grants are provided by our parent organisation IAVS, while EDGG might provide some additional travel grants from own money. Travel grants are only available to members of IAVS in 2019. Priority for travel grants have three groups of persons: (a) participants of at least four previous Field Workshops, (b) specialists for bryophytes and lichens or persons who offer to analyse the soil samples, and (c) persons who offer to host one of the future Field Workshops (as they are required to have participated in at least one Field Workshop before they can host one themselves). The amount of money provided to a particular grantee is not a fixed sum, but depends on the available money, the demonstrated need of the respective person and his/her relevance for the success of the Field Workshop. Accordingly travel grants can cover parts of the registration fee, the full registration fee or possibly even the travel costs to get to the event. Recipients of IAVS travel grants are expected to give an oral presentation related to the topic of the Field Workshop.

You should always apply according to the rules for IAVS travel grants, but we will automatically assign you to the EDGG travel grants (which, for example, do not require to give a presentation) where possible. If you would like to apply for travel grants for both Field Workshops you have to submit one travel grant application with each Field Workshop application.

If you wish to apply for a travel grant, please provide the following additional pieces of information together with your normal applications:

- IAVS member in 2019 (Yes/No)

- Specification whether you have already applied or plan to apply for another IAVS travel grant (e.g. IAVS Symposium, EVS conference or Eurasian Grassland Conference) in 2019

- Number of previous Field Workshops that you participated in

- Indication whether you are member of the current (2017-2019) or future (2019-2021) Executive Committee of EDGG

- Indication whether you are a bryophyte or lichen specialist or whether you are willing to analyse the soil samples

- Indication whether you are willing to organise a future Field Workshop (give target region and potential years)

- Motivation letter (see above, essential for all with less than four prior attendances)
- Approximate travel costs from your place to the starting point of the Field Workshop and back

- How much other funding do you receive (e.g. from your institution)?

- Could you participate if you do not get a travel grant?

- Title of your planned presentation (you will have to give one if you are supported by IAVS)

\section{2th EDGG Field Workshop: Inneralpine dry val- leys of Switzerland (On the trails of Josias Braun -Blanquet II), 11-19 May 2019}

\section{Topic and aims of the Field Workshop}

Braun-Blanquet (1961) in his monograph of the inneralpine xerothermic vegetation provided a profound study of the dry grasslands and other elements of the xerothermic vegetation complexes, such as dry forests and dry ruderal communities. Inneralpine dry valleys refer to those deeply insected, mostly east-west oriented valleys in the (central) Alps that through their morphology and geographic position receive very low rainfall, sometimes even with slightsummer drought, combined with very high solar insolation. Therefore, these valleys in some respect have a climate that resembles that of continental steppes. BraunBlanquet (1961) distinguished 13 such inneralpine xerothermic "islands", from the Durance valley (France) in the Southwest to Carinthia and Styria (Austria) in the East. Six of these islands are particularly extreme with annual precipitation values often below $600 \mathrm{~mm}$ or locally even below $500 \mathrm{~mm}$ : Durance valley (France), Maurienne and Tarentaise (France), Susa-Bardonecchia and Fenestrelle (Italy), Aosta (Italy), Valais (Switzerland) and Vintschgau (Italy).

While the 11th EDGG Field Workshop studied the three Austrian xerothermic "islands", which are the least extreme, Carinthia and Styria, Puster and upper Drau valley and the Inn valley in Tyrol, the 12th EDGG Field Workshop now deals with the Swiss sites, namely the continuation of the Tyrolian Inn valley on Swiss side (called Engadine), the valleys of Central Grisons (Rhine and tributaries) and the Valais (Rhone valley) as one of the most extreme xerothermic islands of the Alps.

The sampling has two main aims: (a) to analyse the biodiversity patterns of the dry grasslands in these valleys across multiple taxonomic groups and grain sizes and (b) to study the syntaxonomic position of these grasslands from a European perspective. Understanding the biodiversity patterns is particularly interesting in comparison with the main distribution ranges of continental and subcontinental dry grasslands in Europe (Turtureanu et al. 2014; Kuzemko et al. 2016) and in the overall framework of the Palaearctic (see Dengler et al. 2016a). We are also curious whether our findings are similar to Austria (see Magnes et al. 2018) and the Aosta valley (Wiesner et al. 2015).

Addressing the syntaxonomic position of the dry grasslands in the inneralpine dry valleys of Switzerland is particularly 
relevant as there were essentially no broad-scale, datadriven syntaxonomic syntheses of the dry grassland vegetation since Braun-Blanquet (1961), while elsewhere in Europe there had been big advancement (e.g. Willner et al. 2017, 2019). Currently, Swiss geobotanists largely use the typology of habitats of Switzerland (Delarze et al. 2015), whose units mostly correspond to phytosociological alliances. In this book at least xeric and meso-xeric communities are separated at alliance level, whereas BraunBlanquet (1961) mostly joined them in single regional associations. However, other recent developments of the dry grassland classification are not reflected and evident problems not addressed, e.g.: (i) In Central and Eastern Europe, the xeric Festuco-Brometea communities are since long split into one order on deep soils (Festucetalia valesiacae; E1.2b in Schaminée et al. 2016) and one on rocky sites (Stipo pulcherrimae-Festucetalia pallentis; E1.1g), while in Switzerland both types are still merged under the name "Stipo-Poion", despite species and communities of both groups being widespread (see Schaminée et al. 2016; J. Dengler unpubl. observations). (ii) While the delimitation of the two vicariant alliances of meso-xeric grasslands Cirsio-Brachypodion pinnati and Bromion erecti has internationally been well elaborated (Willner et al. 2019), their distinction and distribution in Switzerland is still only vaguely known (see Delarze et al. 2015). Possibly the inneralpine meso-xeric stands with Brachypodium rupestre instead of $B$. pinnatum might even be closer to the Apennine alliance Polygalo mediterraneae-Bromion erecti. (iii) The maps in Delarze et al. (2015) suggest that in the inneralpine dry valleys of Switzerland three alliances of shallow skeletal soils should occur side by side (Alysso-Sedion, Sedo -Veronicion, Sedo-Scleranthion), which raises the question how are they distinguished floristically and ecologically.

The data collected during this Field Workshop will be used by the participants for joint scientific publications. They will be joined with some other recent data with identical or similar sampling: (i) J. Dengler et al. (see Dengler 2018; Dengler et al. in prep.) sampled the dry grasslands of Ausserberg, Valais, with $10-\mathrm{m}^{2}$ plots and EDGG Biodiversity Plots; (ii) J. Dengler's research group sampled the dry grasslands of the military training area "Calanda" in Chur (Rhine valley) with $10-\mathrm{m}^{2}$ plots; (iii) J. Dengler's group will conduct an international summer school "Biodiversity Monitoring" in the Albula valley (between the Rhine valley and the Engadine) in August 2019, including sites for the DarkDivNet network (see https://www.botany.ut.ee/ macroecology/en/darkdivnet), whose dry grassland plots will be recorded as EDGG Biodiversity Plots. All data from the Field Workshop will be fed into the EDGG-associated GrassPlot database (Dengler et al. 2018) and into the emerging Swiss national vegetation database (working title "Veg.CH").

\section{Fauna, flora and vegetation}

As a consequence of their climate, the inneralpine dry valleys in general host animal and plant species as well as vegetation types adapted to these conditions that are oth- erwise absent or rarely found in the entire Alps. Among these particular species are many that are typical for the steppic grasslands of eastern Central Europe and the steppes of Eastern Europe. Here they have an isolated outpost of their distribution range, often their westernmost occurrences. The consequence of this isolation is that some taxa even formed endemic species or subspecies restricted to the inneralpine dry valleys. This diverse steppic element is enriched with widespread Central European dry grassland species and some (sub-) Mediterranean species adapted to summer drought. The distribution patterns of dry grassland species of Swiss inneralpine dry valleys is exemplified by four typical maps of vascular plants (Fig. 1).

In general, flora and fauna are very diverse and include many rare and threatened species. According to $\mathrm{P}$. Wiedemeier (ZHAW, pers. comm.), the south-facing slopes above the Rhone in the Canton of Valais are among the richest sites in terms of butterfly species of that size (i.e. a few square kilometres) in the whole of Europe. Some typical vascular plant, non-vascular plant and animal species are shown on Fig. 2. Switzerland has extensive online information platforms for its biodiversity, including detailed distribution maps for nearly all macroscopic species: vascular plants (https://www.infoflora.ch/en/), bryophytes (https:// www.swissbryophytes.ch/index.php/de/verbreitung), lichens (http://merkur.wsl.ch/didado/swisslichens.map), fungi (https://www.wsl.ch/didado/ fungusweb2.search map?sprache app=E) and animals (https://lepus.unine.ch/carto/index.php?lang=en).

The bedrock in the Swiss inneralpine valleys is diverse, but often neither limestone nor very acidic (i.e. granite, gneiss), but rather types that lead to soils of intermediate soil $\mathrm{pH}$, thus hosting a vegetation with a conspicuous mixture of basiphytes and acidophytes. Vegetation types of the xerothermic vegetation complexes are quite diverse (Braun-Blanquet 1961; Dengler 2018). We will focus on all types of dry grassland communities of the class FestucoBrometea (xeric, meso-xeric, rocky), but also include stands of rocky outcrops (Sedo-Scleranthetea) and tall-forb communities of dry, nutrient-poor sites (Trifolio-Geranietea) if they cover some spatial extent, rather than occur as punctual or linear elements. Thus our sampling will mainly deal with the following alliances (nomenclature according to Mucina et al. 2016): Stipo-Poion xerophilae, Festucion valesiacae (hitherto not recognized in Switzerland), CirsioBrachypodion pinnati, Bromion erecti, Sedo albi-Veronicion dillenii, Sedo-Scleranthion, Alysso alyssoidis-Sedion and Geranion sanguinei.

\section{Itinerary of the Field Workshop}

Our itinerary (Table 1, Fig. 3) includes all the inneralpine dry valleys of Switzerland, from west to east: the Rhone valley (Figs. 4a-b), the Rhine valley (Fig. 4c) and the Inn valley (whose Swiss part is called Engadine; Fig. 4d), always with their tributaries. The Rhone valley belongs to the Canton of Valais (speaking German and French) and the other two valleys to the Canton of Grisons (speaking German and Rhaeto-Romanic). We stay in four different accommoda- 
a

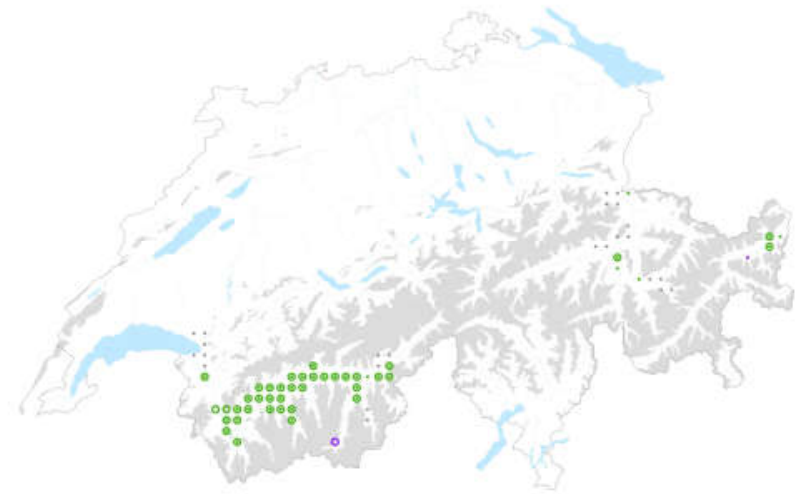

C

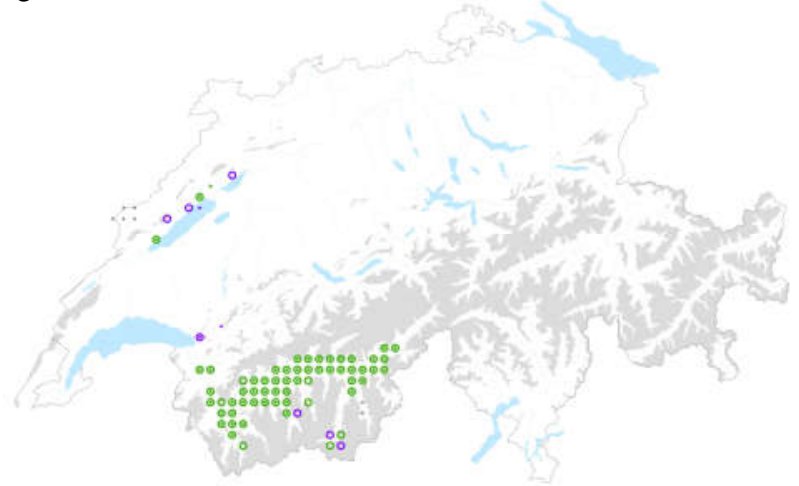

b

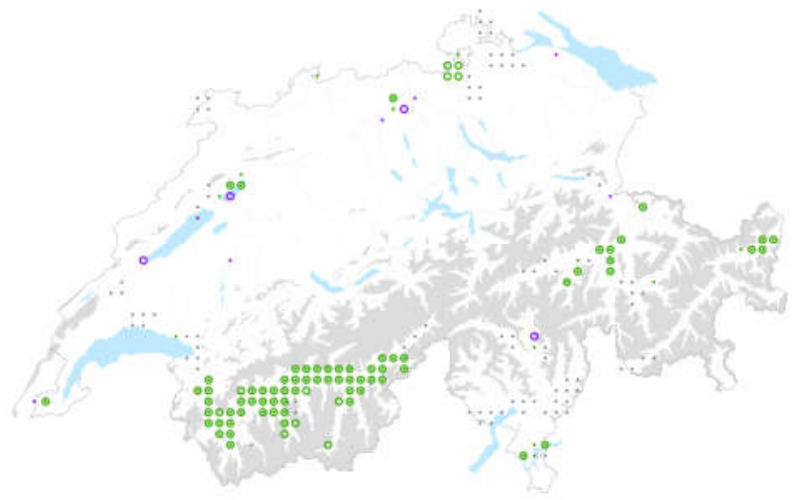

d

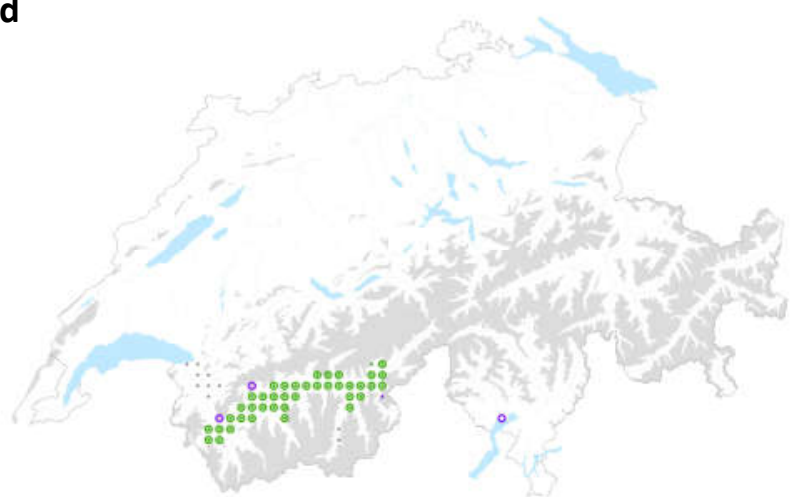

Fig. 1. Distribution of four typical vascular plant species of Swiss inneralpine dry valleys: (a) Stipa capillata, (b) Odontites luteus (both eastern steppic elements), Koeleria vallesiana (western element, widespread in dry grasslands of the Iberian Peninsula) and Centaurea valesiaca (endemic). Maps kindly provided by https://obs.infoflora.ch/app/atlases/en/index.html. Dots are observations before 2002, circles after 2002; green symbols refer to approved records, violet to not (yet) approved records.

tions, each for one to three nights, and each providing us with a group room. One day is planned in Wergenstein (above the Posterior Rhine), where the Zurich University of Applied Sciences (ZHAW) has its outstation.

Among the three valleys, the Rhone valley is the driest and most continental, followed by the Lower Engadine and the Rhine valley (Fig. 5). The valley bottoms in the studied parts of the valleys are at 370-800 $\mathrm{m}$ a.s.l. (Rhone), 550$950 \mathrm{~m}$ a.s.l. (Rhine and tributaries) and 1030-1500 m a.s.l. (Lower Engadine), but the studied dry grasslands might be located several hundred meters above.

Our sampling includes the regional reserves Naturpark Pfyn-Finges and Naturpark Beverin, but most of the great dry grasslands are not part of natural parks or nature reserves. However, their majority is protected as habitats of national priority in the category TWW (Trockenwiesen und -weiden = dry meadows and pastures). One can easily find and visualise them with the web browser of the Swiss administration (https://map.geo.admin.ch/?lang=en). You only need to select Geocatalog / Nature and Environment / Nature protection / Dry grasslands and Dry grasslands appendix 2. You can zoom in, select one such polygon and click on it. Then its basic data are shown as well as a link to an "objectsheet", which contains a map and a short description, including a list of vegetation types and often also of typical species.

\section{Important travel information}

Starting point of the Field Workshop is Wädenswil in the Canton of Zurich, where we will collect participants from the railway station. Zurich has plenty of connections via train, bus and airplane from most bigger cities in Europe and beyond. You can easily reach Wädenswil from the Zurich airport, the central station (Zurich HB) or the international bus stop in Zurich with the metro (S-Bahn). We intend to leave from Wädenswil on Saturday, 11 May, at approximately 11:00 in the morning and return to Wädenswil/Zurich on Sunday, 19 May, at approximately 16:00 in the afternoon. Please ensure that you organise your train/ bus/flight journeys so that they fit with this plan. Upon request, Jürgen Dengler (juergen.dengler@zhaw.ch) can offer to stay in his flat in Wädenswil on the night before or after the expedition (i.e. 10/11 or 19/20 May) if you otherwise do not have a suitable connection.

We will provide essentially all the equipment needed for field sampling (i.e. measuring tapes, rulers, metal pins, 

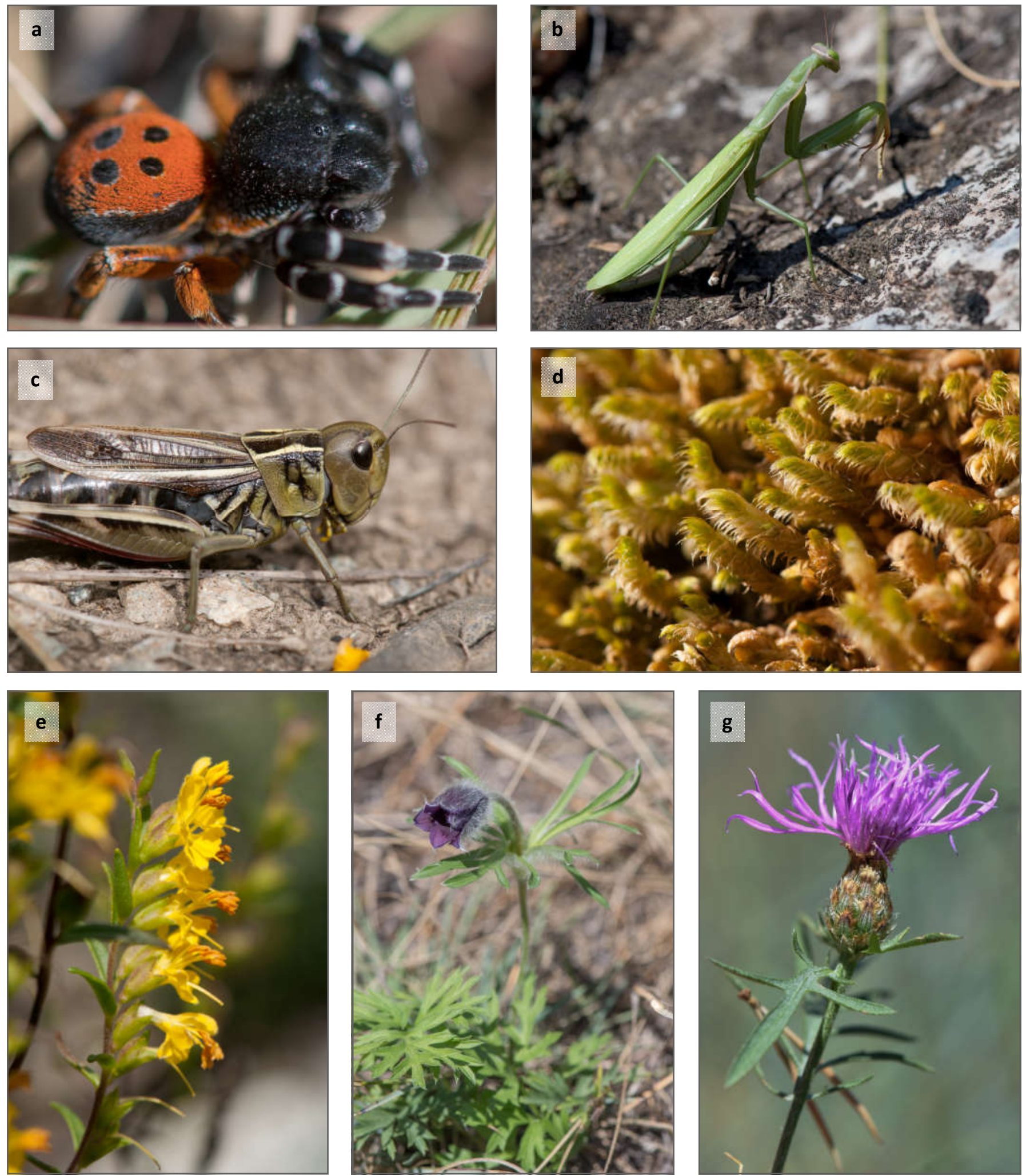

Fig. 2. Some typical species of inneralpine dry valleys of Switzerland: (a) Eresus kollari, Valais; (b) Mantis religiosa, Valais; (c) Arcyptera fusca, Lower Engadine; (d) Rhytidium rugosum, Lower Engadine; (e) Odontites luteus, Valais; (f) Pulsatilla montana, Valais; (g) Centaurea valesiaca, Valais. Photos: J. Dengler. 


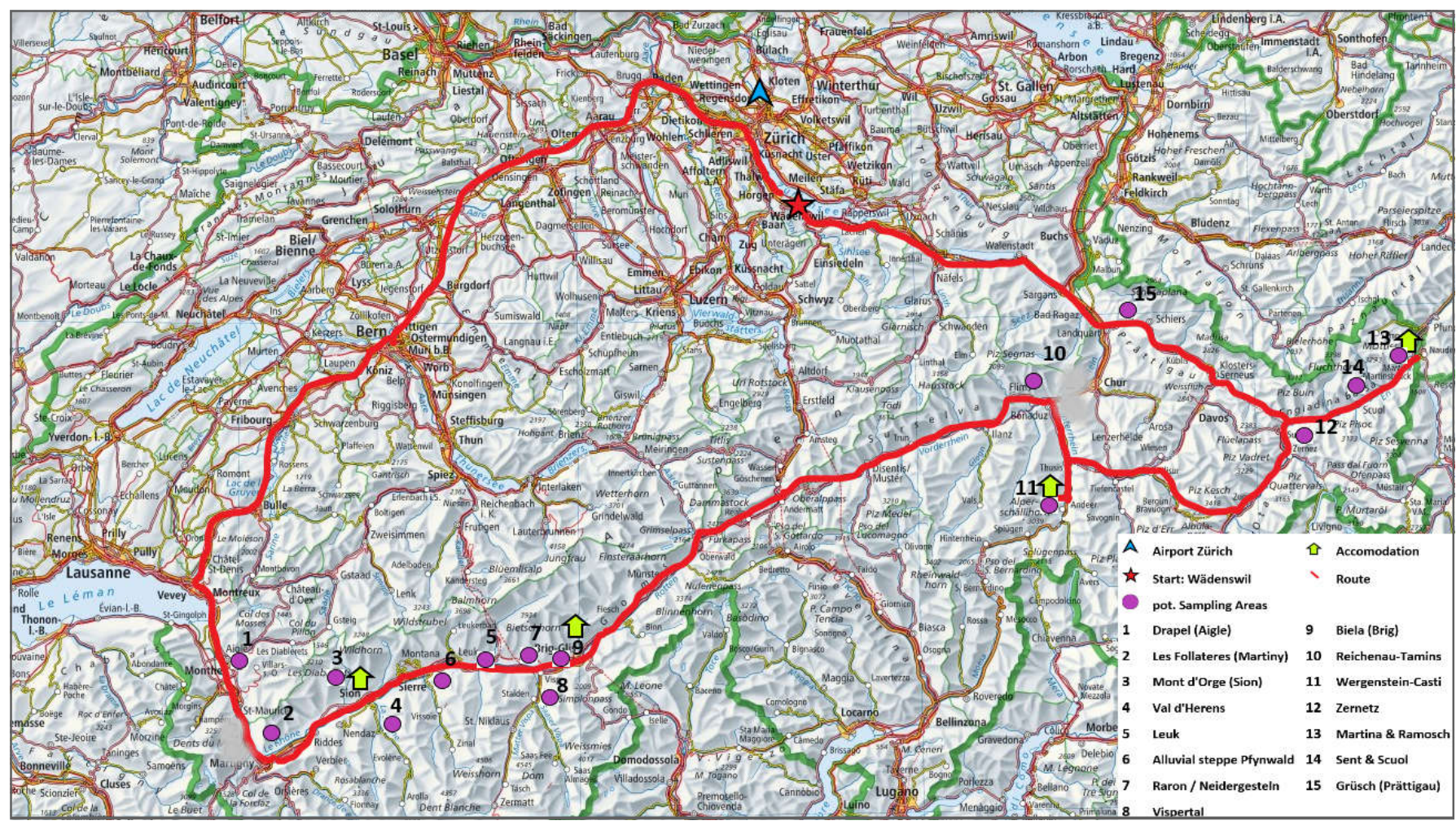

Fig. 3. Itinerary of the 12th EDGG Field Workshop in the inneralpine dry valleys of Switzerland with some confirmed and potential sampling sites marked.

Table 1. Preliminary itinerary of the 12th EDGG Field Workshop in the inneralpine dry valleys of Switzerland.

\begin{tabular}{|c|c|c|c|c|}
\hline Day & $\begin{array}{c}\text { Times } \\
\text { (approx.) }\end{array}$ & $\begin{array}{l}\text { Journey (duration of pure } \\
\text { journey) }\end{array}$ & Dry grassland sites (preliminary) & Accommodation \\
\hline \multirow{2}{*}{$\begin{array}{l}11 \text { May } \\
\text { (Saturday) }\end{array}$} & $11: 00$ & \multirow{2}{*}{ Wädenswil - Sion (3 h) } & \multirow{2}{*}{ On the way: Drapel (Aigle) } & \\
\hline & $18: 00$ & & & \multirow{6}{*}{ Youth Hostel Sion } \\
\hline \multirow{2}{*}{$\begin{array}{l}12 \text { May } \\
\text { (Sunday) }\end{array}$} & $08: 30$ & \multirow{2}{*}{ Around Sion } & \multirow{2}{*}{ Les Follateres (Martiny) } & \\
\hline & 18:00 & & & \\
\hline \multirow{2}{*}{$\begin{array}{l}13 \text { May } \\
\text { (Monday) }\end{array}$} & $08: 30$ & \multirow{2}{*}{ Around Sion } & \multirow{2}{*}{$\begin{array}{l}\text { Morning: Mont d'Orge (Sion); afternoon: } \\
\text { Val d'Herens }\end{array}$} & \\
\hline & $18: 00$ & & & \\
\hline \multirow{2}{*}{$\begin{array}{l}14 \text { May } \\
\text { (Tuesday) }\end{array}$} & $08: 30$ & \multirow{2}{*}{ Sion - Brig (1 h) } & \multirow{2}{*}{$\begin{array}{c}\text { Morning: Leuk; afternoon: Alluvial steppe } \\
\text { Pfynwald }\end{array}$} & \\
\hline & $18: 00$ & & & \multirow{4}{*}{ Hotel Olympica Brig } \\
\hline \multirow{2}{*}{$\begin{array}{c}15 \text { May } \\
\text { (Wednesday) }\end{array}$} & 08:30 & \multirow{2}{*}{ Around Brig } & \multirow{2}{*}{$\begin{array}{c}\text { Morning: Raron / Neidergesteln; after- } \\
\text { noon: Vispertal }\end{array}$} & \\
\hline & $18: 00$ & & & \\
\hline \multirow{2}{*}{$\begin{array}{l}16 \text { May } \\
\text { (Thursday) }\end{array}$} & $08: 30$ & \multirow{2}{*}{ Brig - Wergenstein (2.5 h) } & \multirow{2}{*}{$\begin{array}{l}\text { Morning: Biela (Brig); on the way: Reiche- } \\
\text { nau-Tamins }\end{array}$} & \\
\hline & $18: 00$ & & & Pension Mantarella \\
\hline \multirow{2}{*}{$\begin{array}{l}17 \text { May } \\
\text { (Friday) }\end{array}$} & $08: 30$ & \multirow{2}{*}{$\begin{array}{l}\text { Wergenstein - Martina (2 } \\
\text { h) }\end{array}$} & \multirow{2}{*}{$\begin{array}{c}\text { Morning: Wergenstein-Casti; on the way: } \\
\text { Zernez }\end{array}$} & Donat \\
\hline & $18: 00$ & & & \multirow{4}{*}{$\begin{array}{l}\text { Berghaus Outdoor- } \\
\text { Center Rezia-Martina }\end{array}$} \\
\hline \multirow{2}{*}{$\begin{array}{l}18 \text { May } \\
\text { (Saturday) }\end{array}$} & $08: 30$ & \multirow{2}{*}{ Around Martina } & \multirow{2}{*}{$\begin{array}{l}\text { Morning: Martina \& Ramosch; afternoon: } \\
\text { Sent \& Scuol }\end{array}$} & \\
\hline & $18: 00$ & & & \\
\hline \multirow{2}{*}{$\begin{array}{l}19 \text { May } \\
\text { (Sunday) }\end{array}$} & 08:00 & \multirow{2}{*}{$\begin{array}{l}\text { Martina - Zurich airport / } \\
\text { central station }(3 \mathrm{~h})\end{array}$} & \multirow{2}{*}{ On the way: Grüsch (Prättigau) } & \\
\hline & $16: 00$ & & & \\
\hline
\end{tabular}



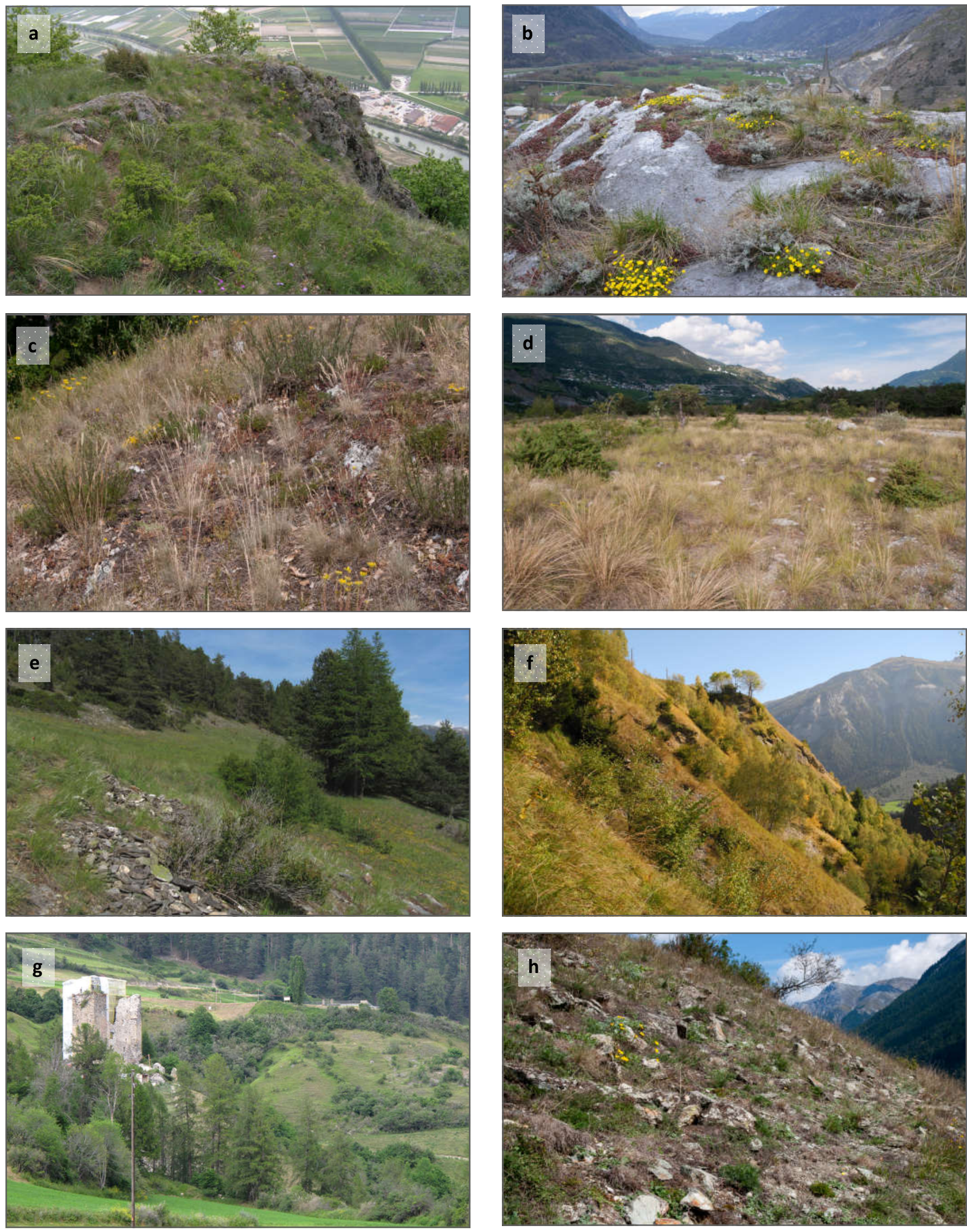

Fig. 4. Examples of dry grasslands in the three study regions of the Field Workshop: (a) rocky steppe "Follateres" above Martigny; (b) rocky steppe "Heidnischbiel", Raron; (c) rocky steppe in Varen; (d) alluvial steppe on gravel deposits of the Rhone in the Pfynwald; (e) dry grasslands in Zeneggen, Vispertal, all Valais; (f) dry grasslands "Casti Nicca" near Wergenstein, Posterior Rhine valley; (g) xerothermic complexes, Tschanueff; (h) dry grasslands in Sent, both Lower Engadine. Photos: a, b, e, g-S. Eggenberg; c, d, h-J. Dengler; f-S. Nagelmüller. 
Visp (Rhone valley) $639 \mathrm{~m}$ a.s.l. [MAT: $9.4^{\circ} \mathrm{C}$; MAP: $596 \mathrm{~mm}$ ]

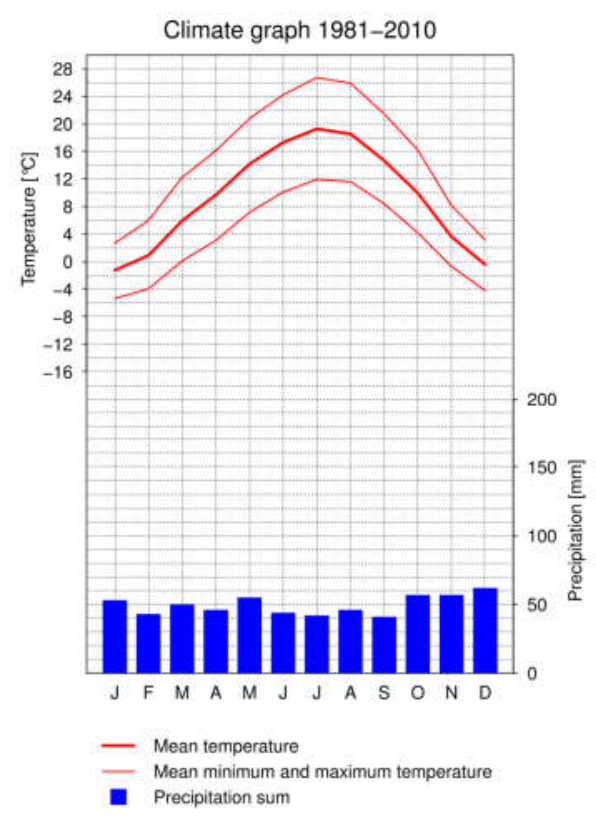

Chur (Rhine valley) $556 \mathrm{~m}$ a.s.I. [MAT: $10.0^{\circ} \mathrm{C}$; MAP: $849 \mathrm{~mm}$ ]
Scuol (Engadine) $1304 \mathrm{~m}$ a.s.l. [MAT: $5.5^{\circ} \mathrm{C}$; MAP: $706 \mathrm{~mm}$ ]
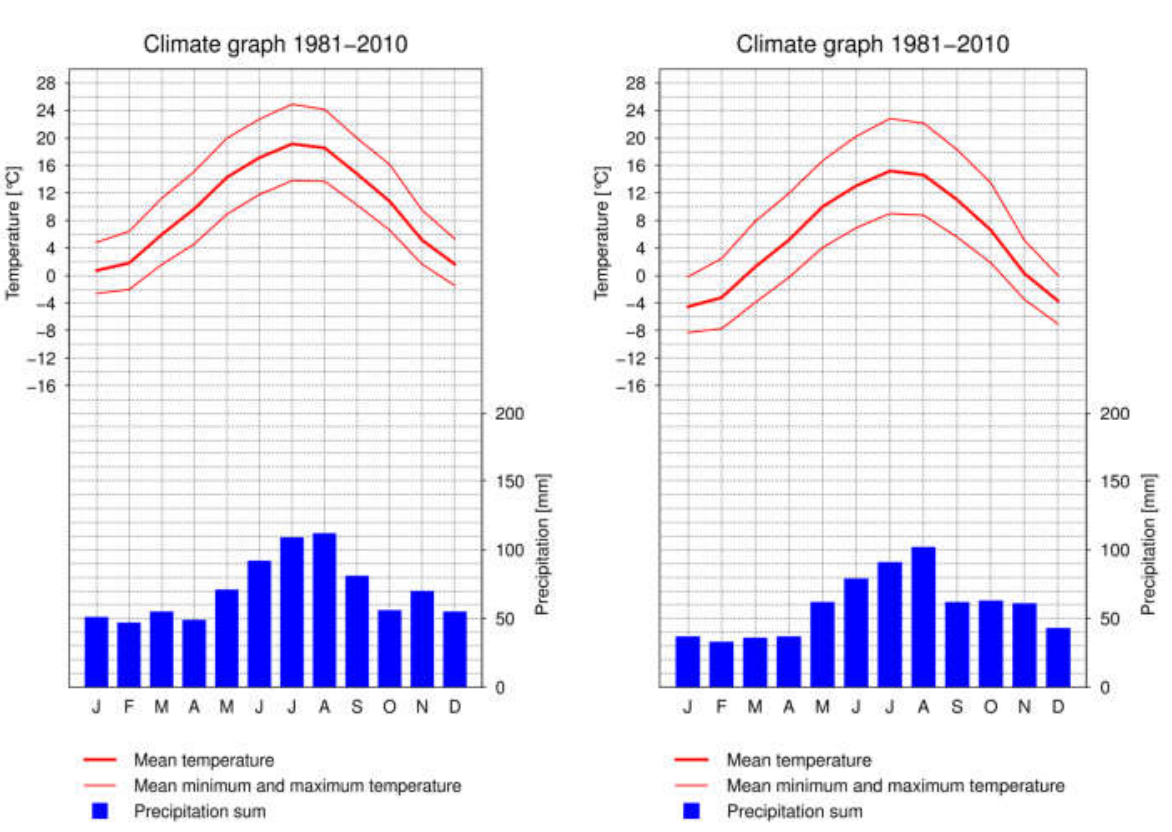

Fig. 5. Climate of three representative stations along our itinerary. Diagrams kindly provided by https:// www.meteoschweiz.admin.ch/home/klima/schweizer-klima-im-detail/klima-normwerte/klimadiagramme-undnormwerte-pro-station.html (MAT: mean annual temperature; MAP: mean annual precipitation).

relevé forms, some penetrometers and GPS devices) as well as a bunch of good floras (in German), a binocular and a microscope. Whether some additional equipment should be brought by participants, will be communicated with the confirmed participants later.

You need to bring a towel with you. Moreover, for our last accommodation in Martina you need bedlinen. If you do not want to carry this with you, you alternatively can rent it for $15 \mathrm{CHF}$ in the place.

\section{Fees and application}

Despite Switzerland being one of the most expensive countries in the world, we can offer participation for a reasonable price due to two reasons: (a) most of the time we will stay in 3- and 4-bed rooms and (b) the Vegetation Ecology Group of ZHAW supports this event financially. The fees comprise all costs of food and beverages (except for alcoholic ones), travelling and accommodation starting on 11 May in Wädenswil and ending on 19 May in Wädenswil or at Zurich airport, as well as a printed "reader" with some basic information on the itinerary and the sites.

The fees for full participation are:

- 700 CHF for postdocs, senior scientists or other regularly employed persons who are not IAVS members

- $600 \mathrm{CHF}$ for postdocs, senior scientists or other regularly employed persons who are IAVS members

- 600 CHF for students, PhD students and unemployed persons who are not IAVS members
- $500 \mathrm{CHF}$ for students, PhD students and unemployed persons who are IAVS members

People who participate for the whole duration can also apply for travel grants, which cover the fees partly or fully (for details see under "Travel grants" above).

Partial participation in the Field Workshop is also possible if there are free places, but only for at least two complete subsequent days and one night. Partial participants who join later than the first day are requested to have studied the methodological instructions very carefully before coming. The fees are without differentiation into categories:

- 80 CHF per night (half board, i.e. dinner and breakfast included)

\section{- 20 CHF per day (picnic included)}

Please understand that we cannot accept any other arrangements (other accommodation, travel during the day independently of the group) for logistic and group-dynamic reasons.

Upon request it might be possible in some of the accommodations to offer 1- or 2-bed rooms if you are willing to cover the additional costs. If interested, you can get into contact with jamyra.gehler@zhaw.ch.

Payment has to be made in cash on the first day of participation, with possible travel grants already subtracted. For cancellations, we charge the following fees:

- Until 20 April: $50 \%$ of your regular fees

- After 20 April: $80 \%$ of your regular fees 
Applications should be sent via e-mail to jamyra.gehler@zhaw.ch AND juergen.dengler@zhaw.ch with all required documents and not later than 31 March 2019. The subject line of the mail should be "EDGG Field Workshop Switzerland". Please carefully read the general information given in the sections "Application" and "Travel grants" above and provide all the documents required. A maximum of 14 (potentially 18) participants is possible, including approx. 4 organisers from the ZHAW. If we should receive more applications than there are available places, we will decide after the deadline according to the criteria listed above in the general part.

If you need an invitation letter for visa application, please get in touch with jamyra.gehler@zhaw.ch as early as possible.

13th EDGG Field Workshop: Grasslands of Armenia along the elevational gradient, 26 June 6 July 2019

\section{Topic and aims of the Field Workshop}

Armenia is a Southern Caucasian republic, bordering with Georgia (in the North), Azerbaijan (in the East), Turkey (in the West and South-West), and Iran (in the South). It is a landlocked country with a total area of $29,740 \mathrm{~km}^{2}$ $(2,974,259 \mathrm{ha})$ with a total of $1479 \mathrm{~km}$ of border, at a distance of about $145 \mathrm{~km}$ from the Black Sea, $175 \mathrm{~km}$ from the Caspian Sea, $750 \mathrm{~km}$ from the Mediterranean Sea and $960 \mathrm{~km}$ from the Persian Gulf. It lies between $38^{\circ} 50^{\prime}$ and $41^{\circ} 18^{\prime}$ northern latitude and between $43^{\circ} 27^{\prime}$ and $46^{\circ} 37^{\prime}$ eastern longitude, and measures $400 \mathrm{~km}$ along its main axis (north-west to south-east) and $200 \mathrm{~km}$ (east-west), with a narrow projection (Zangezur) in the south-east. Armenia is a mountainous country, having its lowest point of $375 \mathrm{~m}$ a.s.l. and culminating at $4095 \mathrm{~m}$ a.s.l. with an average altitude of $1850 \mathrm{~m}$ a.s.l. (76.5\% of its territory is 1000 $2500 \mathrm{~m}$ a.s.l.).

Four main geomorphological regions can be recognized within Armenia. 1. Mountain ridges and valleys in the north-east of the country which bear witness of extensive erosion. 2. Areas covered by lava of relatively recent (upper Pliocene) origin within Asia Minor characterized by gentle slopes with little evidence of erosion but, in which larger rivers have carved out deep gorges and canyons. 3. A series of ridged mountains in the south of Armenia, which constitute the Minor Caucasus system and show intense erosion. 4. The Ararat Valley representing the lowest part of the Ararat depression which is covered with alluvial and proluvial sediments.

A wide range of climatic zones have been recorded within Armenia. The country is located centrally in the subtropical zone, and thus is dominated by arid to semi-desert conditions. The altitudinal zonation adds diversity resulting from altitudinal clines. In general the climate is best characterised as dry continental, in some areas with an annual rhythm more or less similar to the Mediterranean one. The average temperature varies from $2.7^{\circ} \mathrm{C}$ to $14.1^{\circ} \mathrm{C}$. Average annual precipitation is around $600 \mathrm{~mm}$; it varies depending on altitude from 250 to $1000 \mathrm{~mm}$. Most precipitation falls in the spring. Long-lasting snow cover exists in the mountains above $1300 \mathrm{~m}$, where the annual snowfall could attain $2 \mathrm{~m}$. In the northern part of Armenia humidity comes from the Black Sea in the west, in the southern part from the Caspian Sea in the east, the central part is in the rain shadow of mountain ridges and is therefore the driest area (Fig. 6).

There is only one big river in Armenia - Arax, but the river net is rather dense -215 rivers longer than $10 \mathrm{~km}$. There are many lakes in Armenia. Lake Sevan is the most famous and important for economy and biodiversity conservation.

The sampling has two main aims: (a) to analyse the biodiversity patterns of the Armenian grasslands across multiple taxonomic groups and grain sizes and (b) to study the syntaxonomic position of these grasslands in a general European context. Understanding the biodiversity patterns is particularly interesting in comparison with the main distribution ranges of continental and subcontinental dry grasslands in Armenia and in the overall framework of the Palaearctic (see Dengler et al. 2016a).

All data from the Field Workshop will be fed into the EDGG -associated GrassPlot database (Dengler et al. 2018).

\section{Fauna, flora and vegetation}

Armenia occupies a very small area (less than $30,000 \mathrm{~km}^{2}$ ) in the South Caucasus, but it has extremely rich landscape and biological diversity. About 3800 species of vascular plants grow here (about half of the flora of the whole Caucasus), 428 species of algae, 399 species of bryophytes, 464 species of lichens, 4207 species of fungi, and 549 species of vertebrate animals are registered in Armenia. The estimated number of species of invertebrate animals is 17,200 species (Anon. 2014). Flora and fauna of Armenia include 142 plant and 479 invertebrate animal local endemic species. This rich biodiversity is attributed to the natural ecosystem's diversity.

Armenia is situated between two very distinct phytogeographical domains: the Boreal and Ancient Mediterranean Subkingdoms and at the junction of two floristic provinces - Caucasian and Armeno-Iranian (Takhtajyan 1986).

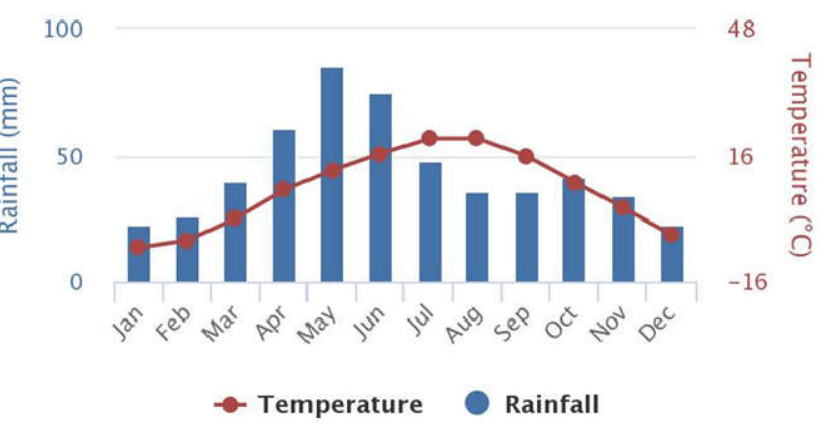

Fig. 6. Average monthly temperature and precipitation in Armenia for the period 1901-2015. 
The peculiarity of each, enhanced by vertical zonation, is the cause of the great variety of the country's vascular flora and vegetation. About 3800 vascular plant species occur on its territory and 12 floristic regions (Fig. 7).

All the main Caucasian ecosystems (besides humid subtropics) are represented in Armenia - deserts and semideserts, steppes, meadow-steppes, forests and open woodlands, sub-alpine and alpine vegetation as well as intrazonal ecosystems. All these represent the habitats of plant and animal species of Armenia.

The diversity of landscapes and orography is an important determinant of Armenia's diverse vegetation. The lower mountain belt (480-1200 $\mathrm{m}$ a.s.l.) is covered by semidesert (or phryganoid) formations, gypsophilous or halophilous vegetation. There are salt marsh areas as well as the Transcaucasian sand desert. The middle and upper mountain belts (1200-2200 m a.s.l.) are characterized by various kinds of steppe and forest vegetation, meadowsteppes, shrub steppes and thorny cushion (tragacanth) vegetation. The altitudinal span of the forest belt varies from 500 to $1500(-2000) \mathrm{m}$ a.s.l. depending of the region, and may approach $2400 \mathrm{~m}$ a.s.l. when open park-like tree stands are included. The subalpine and alpine belts (2200$4000 \mathrm{~m}$ a.s.l.) are covered by meadows and carpets.

\section{Itinerary of the Field Workshop}

Our itinerary (Table 2, Figs. 8-10) includes dry grasslands from seven floristic regions of 12 distinguished in the country (Upper Akhuryan, Shirak, Sevan, Areguni, Aparan, Yerevan, Darelegis).

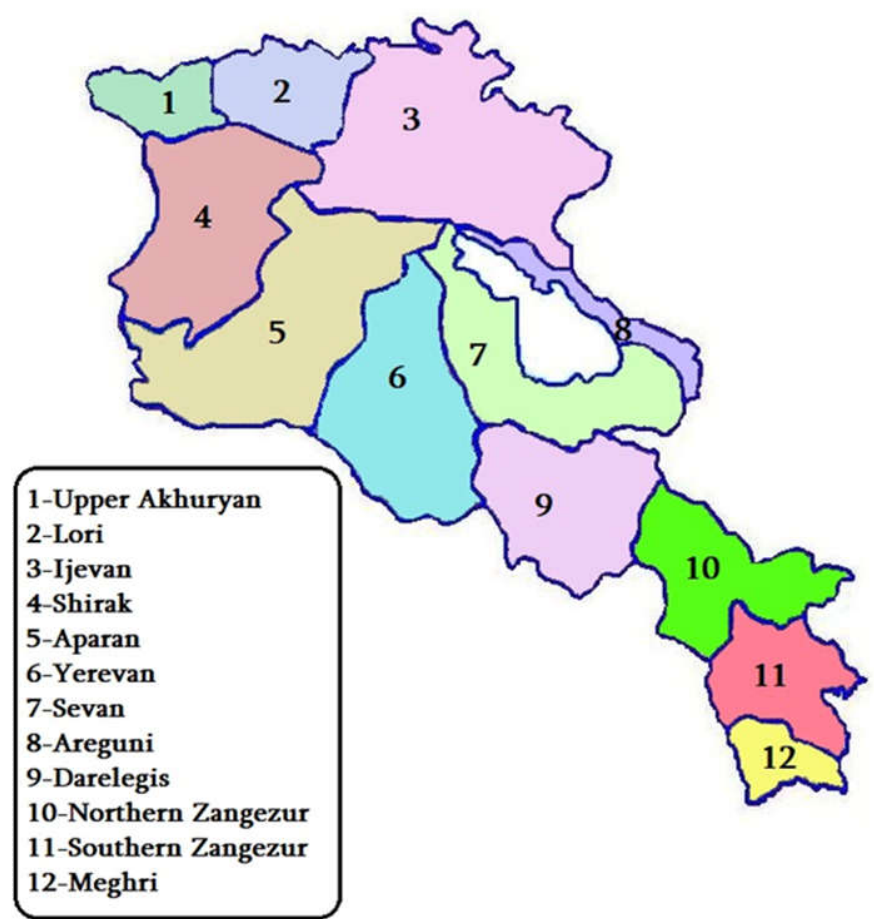

Fig. 7. Map of floristic regions of Armenia (based on data of Tamanyan \& Fayvush 2009).
The studied parts of country are between $850-3000 \mathrm{~m}$ a.s.l.

Because there is no available online data about flora and vegetation of selected sites, below you can find description of habitats classified according to the EUNIS classification (*AM means specific habitats only from Armenia):

- Jajur pass. Very rare habitat in Armenia (F2.33711-AMSteppe shrub with Asphodeline taurica), it is known only from Shirak range in vicinity of Jajur pass.

- Vicinity of Shirakamut village. E1.2E1-AM - Mountain Stipa-Festuca steppes. The most distributed habitats in the steppe belt of Armenia. Steppe scrub with Asphodeline taurica Vicinity of Talin town. E1.2E13-AM Mountain Stipa-Festuca steppes with with dominance of different species of the genus Stipa (Stipa transcaucasica, S. lessingiana, S. capillata).

- Sevan pass. E2.322-AM - Sub-alpine forbs meadows. These habitats are wide distributed in Armenia in upper mountain and sub-alpine belts.

- Vicinity of Sevan town. F7.41212-AM -Traganth communities with dominance of Astragalus lagurus and $A$. aureus. These habitats are common from middle mountain to sub-alpine belt.

- Vicinity of Chkalovka village. E1.2E1-AM - Mountain Stipa-Festuca steppes. The most distributed habitats in the steppe belt of Armenia.

- Selim pass. E2.323-AM - Sub-alpine sedge meadows. These habitats are common in North and Central Armenia.

- Ardanish peninsula. F7.4I21-AM - Traganth milk vetch communities. Very wide distributed habitats in Armenia. They exist in all floristic regions from middle mountain to sub-alpine belt; F7.4I25-AM - Traganth communities with dominance of Acantholimon spp. These habitats are distributed in middle and upper mountain belts in Shirak, Aparan, Areguni, Yerevan, Darelegis and North Zangezur floristic regions.

- Vicinity of Shorja village. E2.162-AM - Forbs meadowsteppes. These habitats are distributed wider than grass meadow-steppes, they are developed on the slopes of different steepness and orientation.

- E1.2E1-AM - Mountain Stipa-Festuca steppes. The most distributed habitats in the steppe belt of Armenia.

- F7.4I21-AM - Traganth milk vetch communities. Very wide distributed habitats in Armenia. They exist in all floristic regions from middle mountain to sub-alpine belt.

- Vicinity of Tigranashen village. F7.4I23-AM - Traganth communities with dominance of Gypsophila aretioides. These habitats are rather rare in Armenia.

- Vicinity of Ararat town. D6.24-AM -Salt marshes with Juncus acutus. These rare habitats are well represented in the East part of Ararat valley in Armenia. 
Table 2. Preliminary itinerary of the 13th EDGG Field Workshop in Armenia.

\begin{tabular}{|c|c|c|c|c|}
\hline Day & $\begin{array}{c}\text { Times } \\
\text { (approx.) }\end{array}$ & $\begin{array}{l}\text { Journey (duration of pure } \\
\text { journey) }\end{array}$ & Dry grassland sites (preliminary) & Overnight \\
\hline \multirow[b]{2}{*}{$\begin{array}{l}26 \text { June } \\
\text { (Wednesday) }\end{array}$} & $14: 00$ & \multirow[b]{2}{*}{ Yerevan-Gyumri (2 h) } & Meeting the group at Yerevan Botanical Gar- & \multirow[b]{2}{*}{ Gyumri } \\
\hline & 18:00 & & $\begin{array}{c}\text { den } \\
\text { Check-in, dinner and presentation about the } \\
\text { study area }\end{array}$ & \\
\hline \multirow{2}{*}{$\begin{array}{l}\text { 27June } \\
\text { (Thursday) }\end{array}$} & 08:30 & \multirow{2}{*}{$\begin{array}{l}\text { Gyumri - Jajur (20 min) } \\
\text { Jajur-Shirakamut (30 min) }\end{array}$} & \multirow{2}{*}{$\begin{array}{l}\text { Morning: Jajur pass } \\
\text { Afternoon: vicinity of Shirakamut village }\end{array}$} & \multirow{2}{*}{ Gyumri } \\
\hline & $18: 00$ & & & \\
\hline \multirow{2}{*}{28 June (Friday) } & $08: 30$ & \multirow{2}{*}{$\begin{array}{l}\text { Gyumri-Amasia (40 min) } \\
\text { Amasia- Aghvorik (40 min) }\end{array}$} & \multirow{2}{*}{$\begin{array}{l}\text { Morning: vicinity of Amasia town } \\
\text { Afternoon: vicinity of Aghvorik village }\end{array}$} & \multirow{2}{*}{ Gyumri } \\
\hline & 18:00 & & & \\
\hline \multirow{2}{*}{$\begin{array}{l}29 \text { June } \\
\text { (Saturday) }\end{array}$} & 08:30 & \multirow{2}{*}{ Gyumri-Talin (1h 10min) } & \multirow{2}{*}{ Vicinity of Talin town } & \multirow{2}{*}{ Gyumri } \\
\hline & 18:00 & & & \\
\hline \multirow{2}{*}{30 June (Sunday) } & 08:30 & \multirow{2}{*}{$\begin{array}{l}\text { Gyumri-Sevan pass ( } 2 \mathrm{~h} 10 \mathrm{~min}) \\
\text { Sevan pass-Sevan town ( } 25 \mathrm{~min})\end{array}$} & \multirow{2}{*}{$\begin{array}{l}\text { Morning: Sevan pass } \\
\text { Afternoon: vicinity of Sevan town }\end{array}$} & \multirow{2}{*}{ Sevan } \\
\hline & 18:00 & & & \\
\hline \multirow{2}{*}{1 July (Monday) } & 08:30 & & Morning: Ardanish peninsula & \multirow{2}{*}{ Sevan } \\
\hline & 18:00 & & Afternoon: vicinity of Shorja village & \\
\hline \multirow{2}{*}{2 July (Tuesday) } & $08: 30$ & \multirow{2}{*}{$\begin{array}{c}\text { Sevan-Chkalovka (20 } \mathrm{min}) \\
\text { Chkalovka-Selim pass (1h } 30 \\
\text { min) }\end{array}$} & \multirow{2}{*}{$\begin{array}{l}\text { Morning: vicinity of Chkalovka village } \\
\text { Afternoon: Selim pass }\end{array}$} & \\
\hline & 18:00 & & & Yeghegnadzor \\
\hline \multirow{2}{*}{$\begin{array}{c}3 \text { July } \\
\text { (Wednesday) }\end{array}$} & 08:30 & \multirow{2}{*}{$\begin{array}{l}\text { Yeghegnadzor-Areni (20 min) } \\
\text { Areni-Khachik (40 min) }\end{array}$} & \multirow{2}{*}{$\begin{array}{l}\text { Morning: vicinity of Areni village } \\
\text { Afternoon: vicinity of Khachik village }\end{array}$} & \multirow{2}{*}{ Yeghegnadzor } \\
\hline & 18:00 & & & \\
\hline \multirow{2}{*}{ 4July (Thursday) } & 08:30 & \multirow{2}{*}{$\begin{array}{l}\text { Yeghegnadzor- Agarakadzor (15 } \\
\text { min) } \\
\text { Agarakadzor -Gnishik (20 min) }\end{array}$} & \multirow{2}{*}{$\begin{array}{l}\text { Morning: vicinity of Agarakadzor village } \\
\text { Afternoon: vicinity of Gnishik village }\end{array}$} & \multirow{2}{*}{ Yeghegnadzor } \\
\hline & 18:00 & & & \\
\hline \multirow{2}{*}{5 July (Friday) } & 08:30 & \multirow{2}{*}{$\begin{array}{l}\text { Yeghegnadzor- Tigranashen }(2 \mathrm{~h}) \\
\text { Tigranashen-Ararat (40 min) }\end{array}$} & \multirow{2}{*}{$\begin{array}{l}\text { Morning: vicinity of Tigranashen village } \\
\text { Afternoon: Vicinity of Ararat town }\end{array}$} & Yereyan \\
\hline & 18:00 & & & rerevan \\
\hline 6 Julv (S & 08:30 & Yerevan-Kari lake (1h 30 min) & Morning: vicinity of Kari lake & \\
\hline 6 July (saturaay) & $18: 00$ & Kari lake-Amberd castle (30 min) & Afternoon: vicinity of Amberd castle & rerevan \\
\hline
\end{tabular}

- Vicinity of Kari lake. E4.3A2-AM - Alpine forbs meadows - alpine carpets. These habitats are very widely distributed on all volcanic massives in Armenia.

- Vicinity of Amberd castle. E2.322-AM - Sub-alpine forbmeadows. These haabitats are widely distributed in Armenia in the upper mountain and sub-alpine belts.

You can find more information about habitats of Armenia in Fayvush \& Aleksanyan (2016).

\section{Important travel information}

Starting point of the Field Workshop is Yerevan Botanical Garden, where we will collect the participants. Yerevan has good international airplane connections. You can easily reach Yerevan Botanical Garden from Zvartnots airport (http://www.zvartnots.aero) using public transport or taxi. We intend to leave from Yerevan Botanical Garden on Wednesday, 26th June, at approximately 14:00 in the afternoon and FW will be finished on Saturday, 06 July, at approximately 20:00 in the evening. We can leave you in the city centre or at the airport. Please ensure that you organise your flight journeys so that they fit with this plan. Please book accommodation yourself if you need it on the night before or after the expedition (i.e. 25/26 June or/and $06 / 07$ July). If you do not have a suitable connection you can contact Alla Aleksanyan (alla.alexanyan@gmail.com) for assistance.

We will provide a bunch of good floras (in Russian). Other equipment that participants should bring with them will be communicated with the participants later.

\section{Fees and application}

The fees comprise all costs of food and beverages (except for alcoholic ones), travelling and accommodation starting in Yerevan Botanical Garden on 26 June and ending on 6 July in Yerevan, as well as a printed "reader" with some basic information on the itinerary and the sites.

The fees for full participation are:

- $800 €$ for postdocs (senior scientists, professors etc.) who are not members of IAVS

- $600 €$ for postdocs (senior scientists, professors etc.) who are members of IAVS

- $700 €$ for young scientists (master and PhD students) as well as unemployed persons who are not member of IAVS

- $500 €$ for young scientists (master and PhD students) as well as unemployed persons who are member of IAVS 


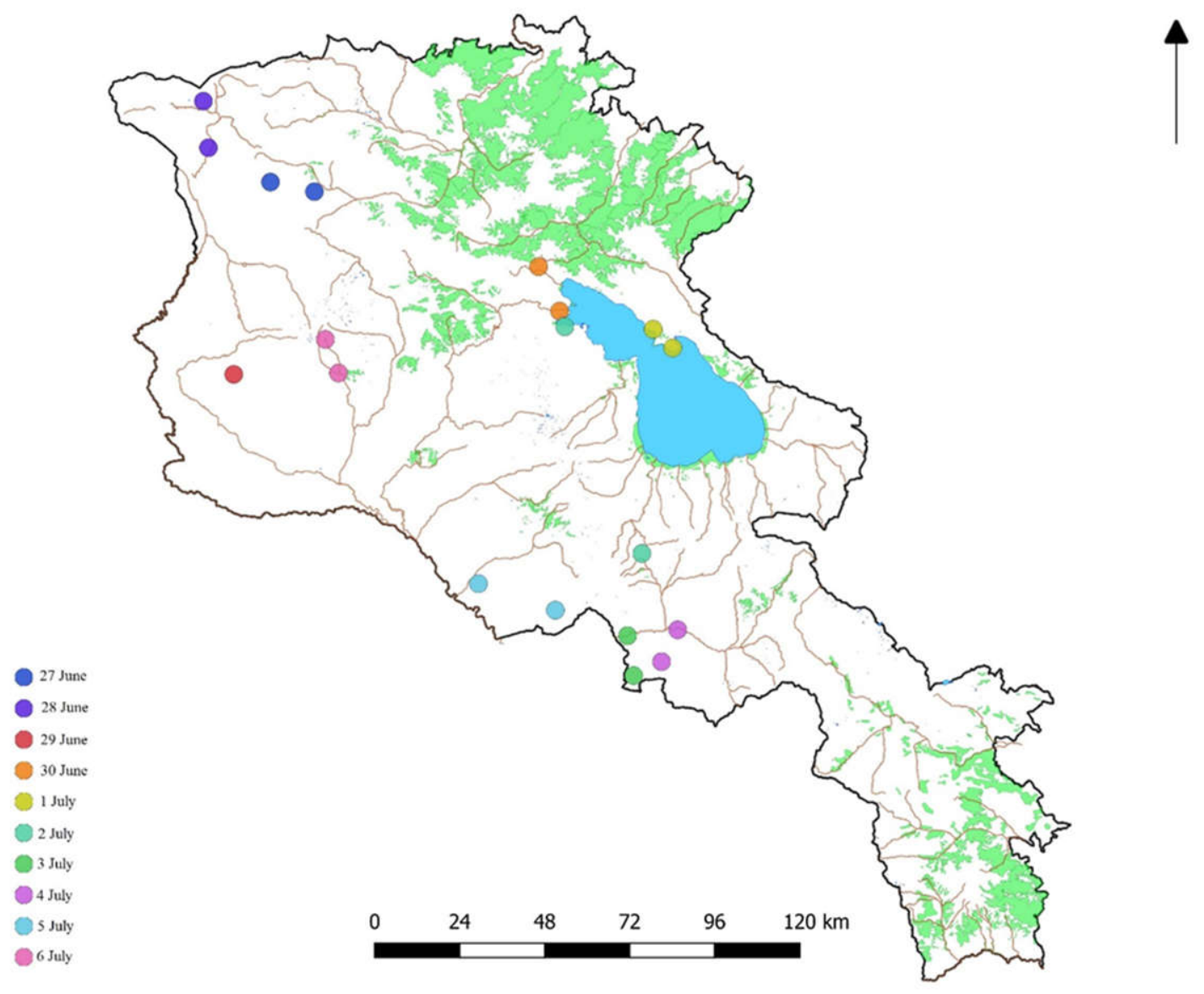

Fig. 8. Itinerary of the 13th EDGG Field Workshop in Armenia with some confirmed and potential sampling sites marked.
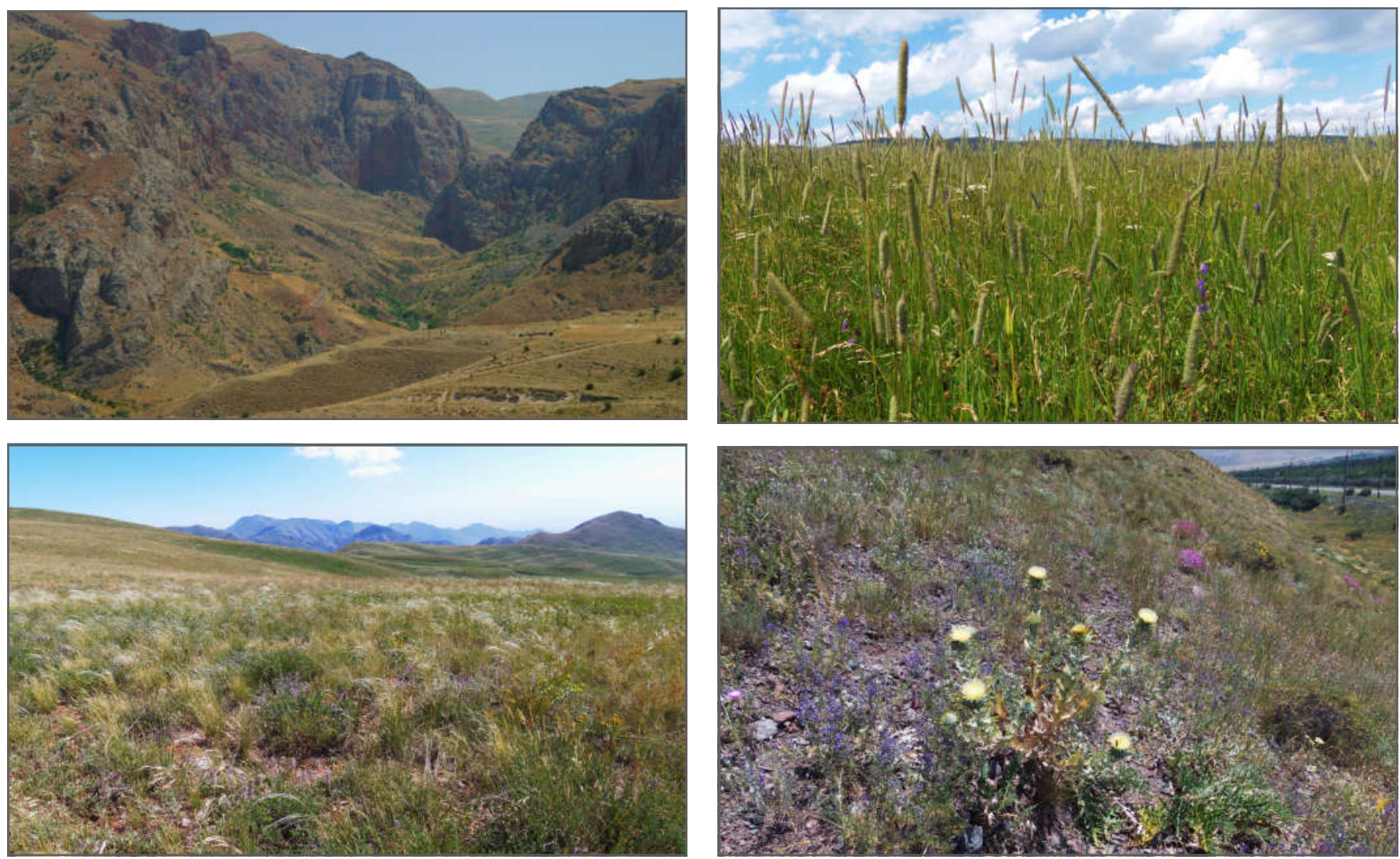

Fig. 9. Examples of dry grasslands in the study regions of the 13th EDGG Field Workshop. From upper left to lower right: Areni-Khachik, Aghvorik, Khachik and Ardanish. Photos: G. Fayvush. 

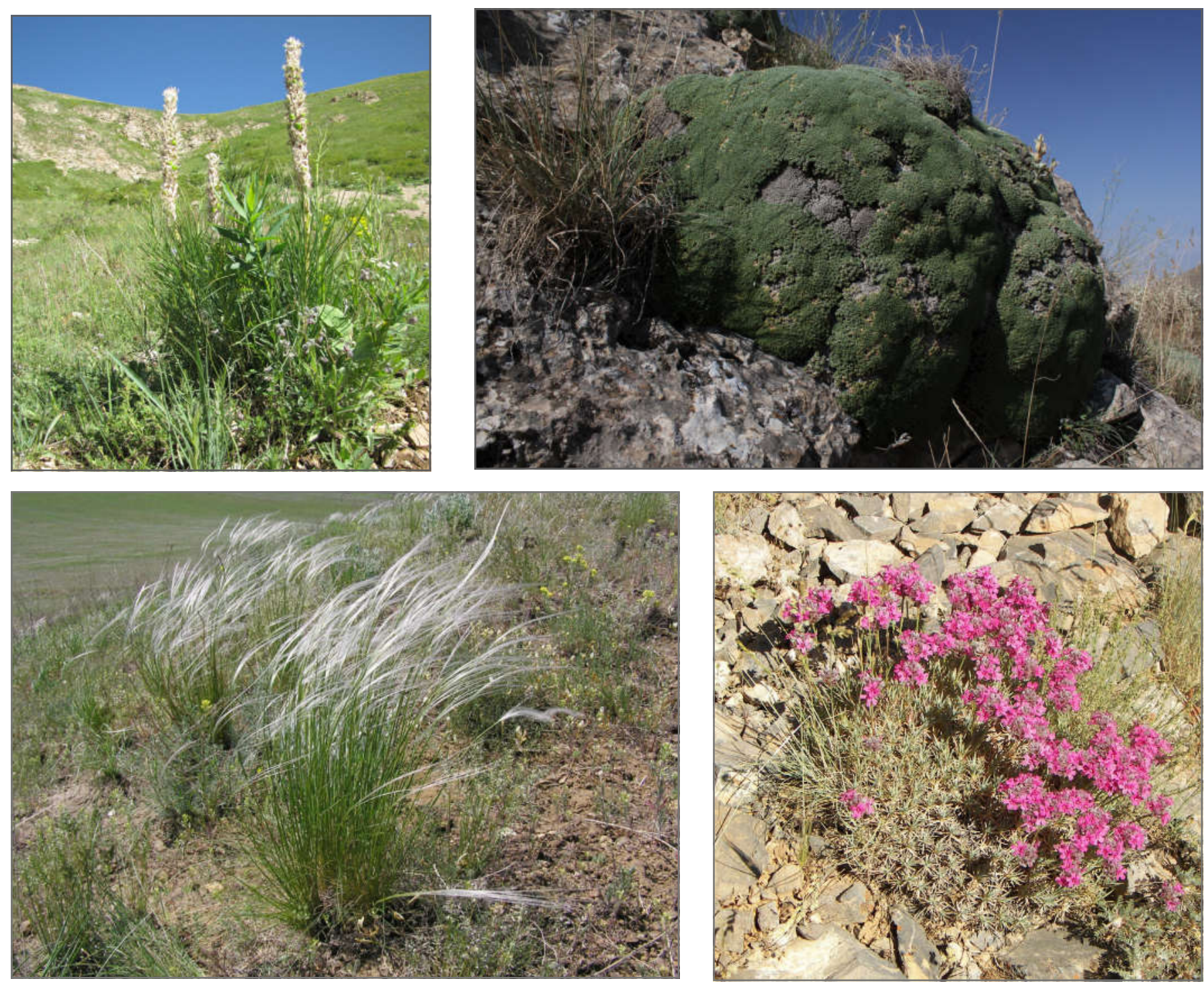

Fig. 10. Some typical species of selected sites in Armenia (from upper left to lower right): Asphodeline taurica, Gypsophila aretioides, Stipa lessingiana, Acantholimon bracteatum. Photos: G. Fayvush.

People who participate for the whole duration can also apply for travel grants, which cover the fees partly or fully (for details see under "Travel grants" above).

Please understand that we cannot accept any other arrangements (other accommodation, travel during the day independently of the group) for logistic and group-dynamic reasons. Upon request it might be possible in some of the accommodations to offer single bed rooms if you are willing to cover the additional costs. If interested, you can get in contact with alla.alexanyan@gmail.com or gfayvush@yahoo.com.

Payment has to be made in cash on the first day of participation, with possible travel grants already subtracted. For cancellations, we charge the following fees:

- Until 30 April: no fees

- From 1-31 May: 50\% of your regular fees

- After 31 May: $80 \%$ of your regular fees
Applications should be sent via e-mail to alla.alexanyan@gmail.com AND gfayvush@yahoo.com with all required documents and not later than 31 March 2019. The subject line of the mail should be "EDGG Field Workshop Armenia". Please carefully read the general information given in the sections "Application" and "Travel grants" above and provide all the documents required. A maximum of 20 participants is possible, including approx. 4 organisers from Armenia. If we should receive more applications than there are available places, we will decide after the deadline according to the criteria listed above in the general part.

If you need an invitation letter for visa application, please get in touch with alla.alexanyan@gmail.com as early as possible.

\section{References}

Anon. 2014. Fifth National Report of the Republic of Armenia to the Convention on Biological Diversity. 2014. Republic of Armenia, Yerevan, AM. 
Braun-Blanquet, J. 1961. Die inneralpine Trockenvegetation. Fischer, Stuttgart, DE.

Bruelheide, H., Dengler, J., Jiménez-Alfaro, B., Purschke, O., Hennekens, S.M., Chytrý M., Pillar, V.D., Jansen, F., Kattge, J., (...) \& Zverev, A. 2019. sPlot - a new tool for global vegetation analyses. Journal of Vegetation Science 30. DOI: 10.1111/ jvs. 12710.

Chytrý, M., Hennekens, S.M., Jiménez-Alfaro, B., Knollová, I., Dengler, J., Jansen, F., Landucci, F., Schaminée, J.H.J., Aćić, S., (...) \& Yamalov, S. 2016. European Vegetation Archive (EVA): an integrated database of European vegetation plots. Applied Vegetation Science 19: 173-180.

Delarze, R., Gonseth, Y., Eggenberg, S. \& Vust, M. 2015. Lebensräume der Schweiz: Ökologie - Gefährdung - Kennarten. 3rd. ed. Ott, Bern, $\mathrm{CH}$.

Dengler, J. 2009. A flexible multi-scale approach for standardised recording of plant species richness patterns. Ecological Indicators 9: 1169-1178.

Dengler, J. 2018. The beauty of xerothermic vegetation complexes in Ausserberg (Rhone valley, Switzerland). Palaearctic Grasslands 38: 34-38.

Dengler, J., Ruprecht, E., Szabó, A., Turtureanu, D., Beldean, M., Uğurlu, E., Pedashenko, H., Dolnik, C. \& Jones, A. 2009. EDGG cooperation on syntaxonomy and biodiversity of FestucoBrometea communities in Transylvania (Romania): report and preliminary results. Bulletin of the European Dry Grassland Group 4: 13-19.

Dengler, J., Becker, T., Ruprecht, E., Szabó, A., Becker, U., Beldean, M., Bita-Nicolae, C., Dolnik, C., Goia, I., (...) \& Uğurlu, E. 2012. Festuco-Brometea communities of the Transylvanian Plateau (Romania) - a preliminary overview on syntaxonomy, ecology, and biodiversity. Tuexenia 32: 319-359.

Dengler, J., Biurrun, I., Apostolova, I., Baumann, E., Becker, T., Berastegi, A., Boch, S., Dembicz, I., Dolnik, C., (...) \& Weiser, F. 2016a: Scale-dependent plant diversity in Palaearctic grasslands: a comparative overview. Bulletin of the Eurasian Dry Grassland Group 31: 12-26.

Dengler, J., Boch, S., Filibeck, G., Chiarucci, A., Dembicz, I., Guarino, R., Henneberg, B., Janišová, M., Marcenò, C., (...) \& Biurrun, I. 2016b. Assessing plant diversity and composition in grasslands across spatial scales: the standardised EDGG sampling methodology. Bulletin of the Eurasian Grassland Group 32: 13-30.

Dengler, J., Wagner, V., Dembicz, I., García-Mijangos, I., Naqinezhad, A., Boch, S., Chiarucci, A., Conradi, T., Filibeck, G., (...), Biurrun, I. 2018. GrassPlot - a database of multi-scale plant diversity in Palaearctic grasslands. Phytocoenologia 48: 331347.

Fayvush, G. \& Aleksanyan, A. 2016. Habitats of Armenia. Zangak, Yerevan, AM.

Filibeck, G., Cancellieri, L., Sperandii, M.G., Belonovskaya, E., Sobolev, N., Tsarevskaya, N., Becker, T., Berastegi, A., Bückle, C. (...) \& Biurrun, I. 2018. Biodiversity patterns of dry grasslands in the Central Apennines (Italy) along a precipitation gradient: experiences from the 10th EDGG Field Workshop. Bulletin of the Eurasian Grassland Group 36: 25-41.

Kuzemko, A.A., Becker, T., Didukh, Y.P., Ardelean, I.A., Becker, U., Beldean, M., Dolnik, C., Jeschke, M., Naqinezhad, A., (...) \& Dengler, J. 2014. Dry grassland vegetation of Central Podolia (Ukraine) - a preliminary overview of its syntaxonomy, ecology and biodiversity. Tuexenia 34: 391-430.

Kuzemko, A.A., Steinbauer, M.J., Becker, T., Didukh, Y.P., Dolnik, C., Jeschke, M., Naqinezhad, A., Ugurlu, E., Vassilev, K. \& Dengler, J. 2016. Patterns and drivers of phytodiversity of steppe grasslands of Central Podolia (Ukraine). Biodiversity and Conservation 25: 2233-2250.

Magnes, M., Mayrhofer, H., Kirschner, P., Stöhr, O., Schwager, P., Dengler, J. \& Biurrun, I. 2018. Invitation and guide to the $11^{\text {th }}$ EDGG Field Workshop. Grasslands of inneralpine dry valleys: part 1, Eastern Alps. Austria, 6-13 July 2018. Bulletin of the Eurasian Dry Grassland Group 36: 12-25.

Mucina, L., Bültmann, H., Dierßen, K., Theurillat, J.-P., Raus, T., Čarni, A., Šumberová, K., Willner, W., Dengler, J., (...) \& Tichý, L. 2016. Vegetation of Europe: Hierarchical floristic classification system of vascular plant, bryophyte, lichen, and algal communities. Applied Vegetation Science 19, Supplement 1: 3-264.

Pedashenko, H., Apostolova, I., Boch, S., Ganeva, A., Janišová, M., Sopotlieva, D., Todorova, S., Ünal, A., Vassilev, K., (...) \& Dengler, J. 2013. Dry grasslands of NW Bulgarian mountains: first insights into diversity, ecology and syntaxonomy. Tuexenia 33: 309-346.

Polchaninova, N., García-Mijangos, I., Berastegi, A., Dengler, J. \& Biurrun, I. 2018. New data on the spider fauna (Araneae) of Navarre, Spain: results from the 7th EDGG Field Workshop. Arachnology Letters 56: 17-23.

Polyakova, M.A., Dembicz, I., Becker, T., Becker, U., Demina, O.N., Ermakov, N., Filibeck, G., Guarino, R., Janišová, M., (...) \& Dengler, J. 2016. Scale- and taxon-dependent patterns of plant diversity in steppes of Khakassia, South Siberia (Russia). Biodiversity and Conservation 25: 2251-2273.

Schaminée, J.H.J., Chytrý, M., Dengler, J., Hennekens, S.M., Janssen, J.A.M., Jiménez-Alfaro, B., Knollová, I., Landucci, F., Marcenò, C. (...) \& Tichý, L. 2016. Development of distribution maps of grassland habitats of EUNIS habitat classification. European Environment Agency [Report EEA/NSS/16/005], Copenhagen, DK.

Takhtajyan A.L. 1986. Floristic regions of the world. University of California Press, Berkeley, CA, US.

Tamanyan K. G. \& Fayvush G. M. 2009. On the problem of floristic regions of Armenia. Flora, Vegetation and Plant Resources of Armenia 17: 73-78.

Turtureanu, P.D., Palpurina, S., Becker, T., Dolnik, C., Ruprecht, E., Sutcliffe, L.M.E., Szabó, A. \& Dengler, J. 2014. Scale- and taxon -dependent biodiversity patterns of dry grassland vegetation in Transylvania (Romania). Agriculture, Ecosystems \& Environment 182: 15-24.

Wiesner, L., Baumann, E., Weiser, F., Beierkuhnlein, C., Jentsch, A. \& Dengler, J. 2015. Scale-dependent species diversity in two contrasting dry grassland types of an inner alpine dry valley (Cogne, Aosta Valley, Italy). Bulletin of the Eurasian Dry Grassland Group 29: 10-17.

Willner, W., Kuzemko, A., Dengler, J., Chytrý, M., Bauer, N., Becker, T., Bita-Nicolae, C., Botta-Dukát, Z., Čarni, A., (...) \& Janišová, M. 2017. A higher-level classification of the Pannonian and western Pontic steppe grasslands (Central and Eastern Europe). Applied Vegetation Science 20: 143-158.

Willner, W., Roleček, J., Korolyuk, A., Dengler, J., Chytrý, M., Janišová, M., Lengyel, A., Aćić, S., Becker, T., (...) \& Yamalov, S. 2019. Formalized classification of the semi-dry grasslands of central and eastern Europe. Preslia 91: 25-49.

Jürgen Dengler (juergen.dengler@zhaw.ch) Jamyra Gehler (jamyra.gehler@zhaw.ch) Alla Aleksanyan (alla.alexanyan@gmail.com) Georgi Fayvush (gfayvush@yahoo.com) Idoia Biurrun (idoia.biurrun@ehu.es) 


\title{
$62^{\text {nd }}$ Annual Symposium of the IAVS "Vegetation Science and Biodiversity Research"
}

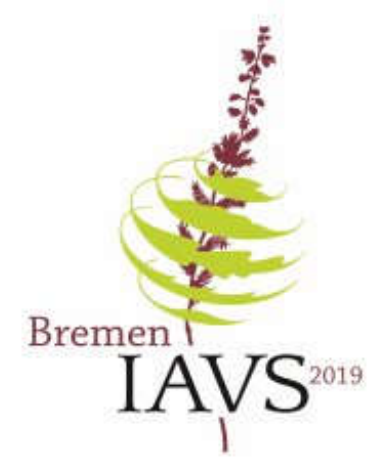

\author{
14-19 July 2019, Bremen \\ Conference website \\ http://iavs.org/2019-Annual-Symposium/Home.aspx
}
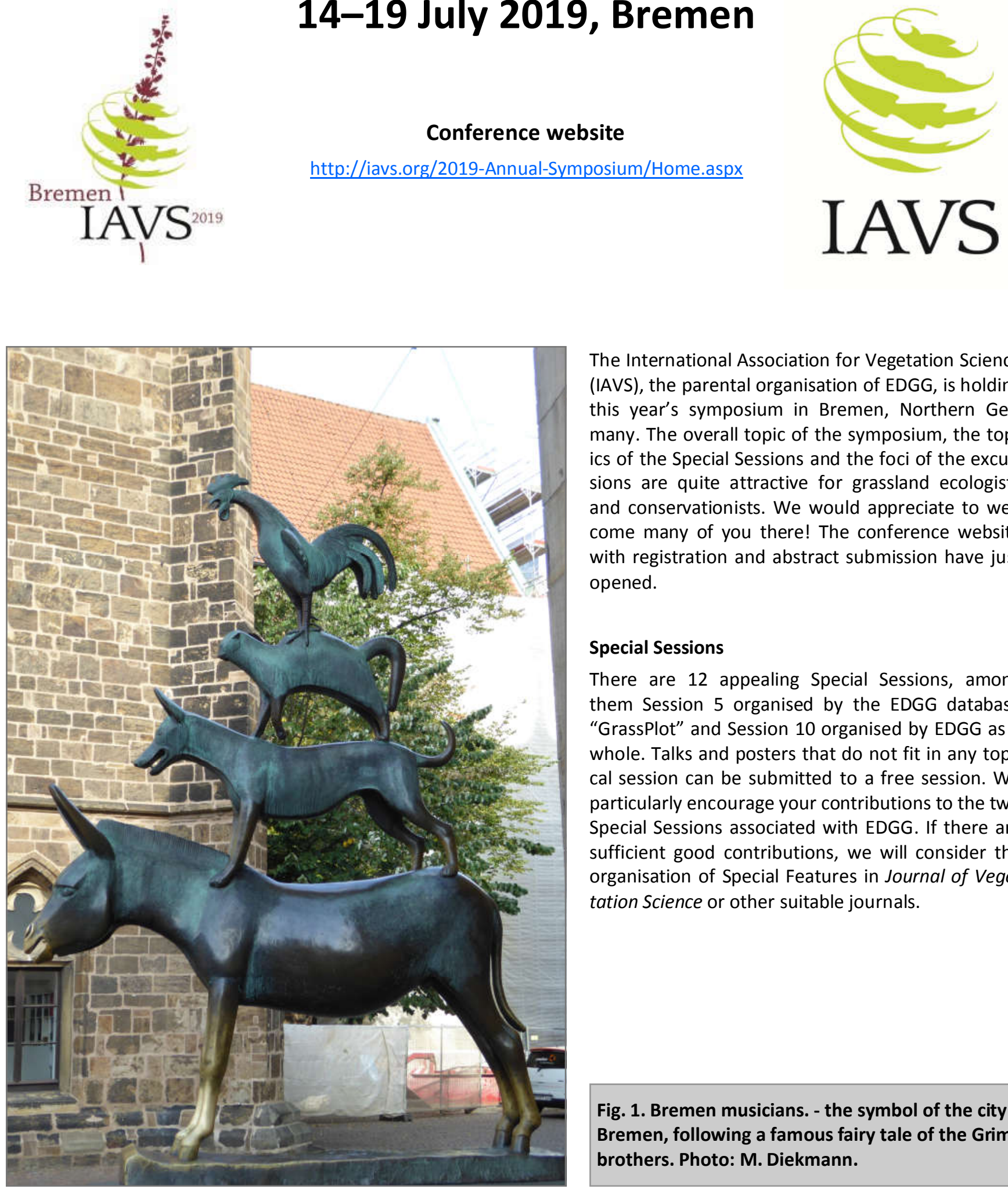

The International Association for Vegetation Science (IAVS), the parental organisation of EDGG, is holding this year's symposium in Bremen, Northern Germany. The overall topic of the symposium, the topics of the Special Sessions and the foci of the excursions are quite attractive for grassland ecologists and conservationists. We would appreciate to welcome many of you there! The conference website with registration and abstract submission have just opened.

\section{Special Sessions}

There are 12 appealing Special Sessions, among them Session 5 organised by the EDGG database "GrassPlot" and Session 10 organised by EDGG as a whole. Talks and posters that do not fit in any topical session can be submitted to a free session. We particularly encourage your contributions to the two Special Sessions associated with EDGG. If there are sufficient good contributions, we will consider the organisation of Special Features in Journal of Vegetation Science or other suitable journals.

Fig. 1. Bremen musicians. - the symbol of the city of Bremen, following a famous fairy tale of the Grimm brothers. Photo: M. Diekmann. 


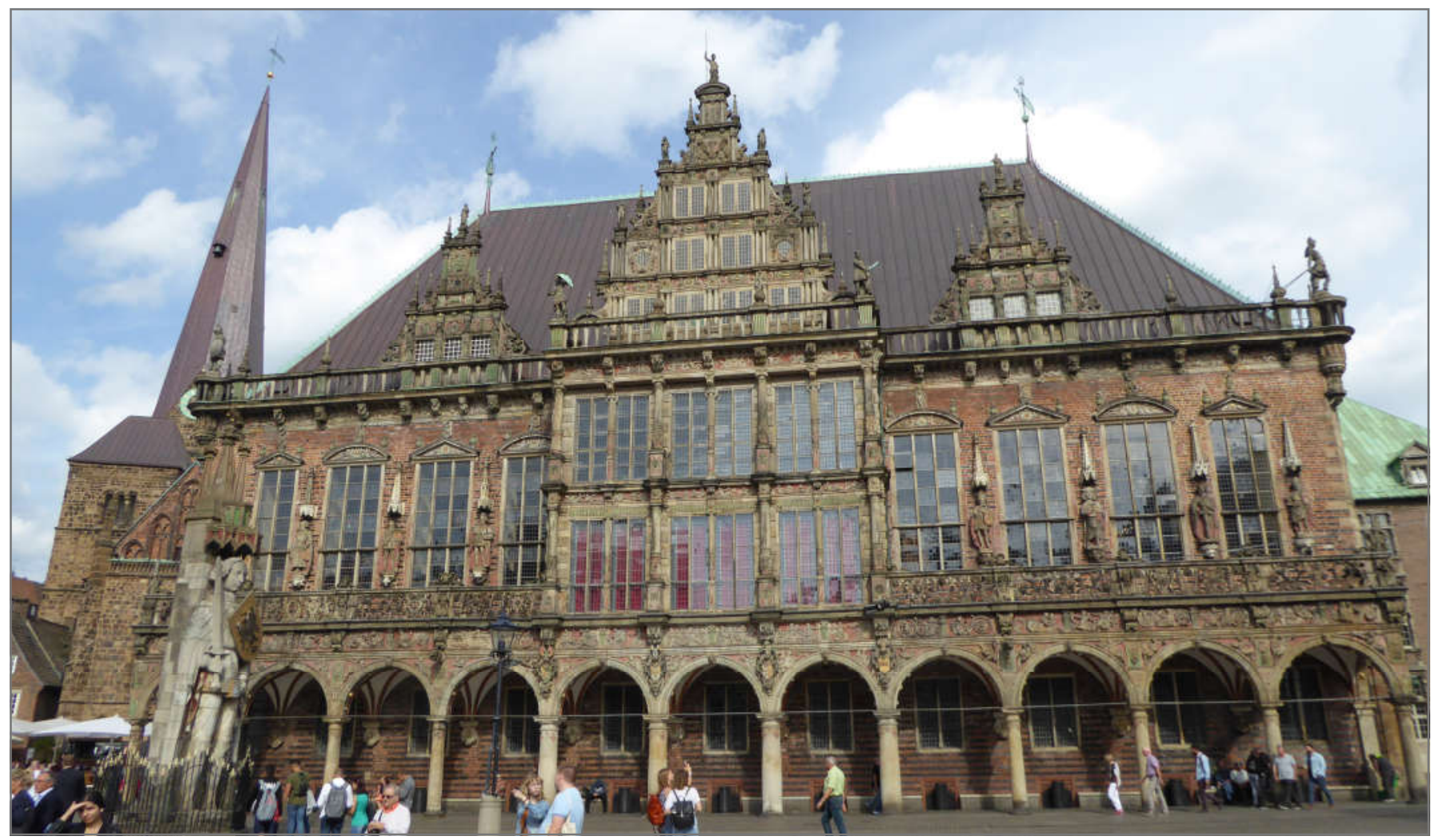

Fig. 2. The famous town hall of Bremen. Bremen is a Hanseatic city of 570,000 inhabitants at the River Weser. Photo: M. Diekmann.

\section{Special Session 5 organised by GrassPlot}

Species-area relationships and other scaling laws in plant biodiversity

\section{Alessandro Chiarucci, Iwona Dembicz \& Jürgen Dengler}

Plant biodiversity, its patterns and drivers are inherently scale-dependent. Species-area relationships (SARs) are the most prominent of such scale dependencies. Despite such SARs have been a major topic of plant ecology for over one century, only recent advances in non-linear modelling and theory combined with large datasets could (largely) dissolve these long-lasting disputes over the nature of species-area relationships. However, there are many other manifestations of scale-dependencies in plant biodiversity, including determination of biodiversity hot-spots, diversityenvironment relationships, relative importance of environmental filtering vs. competitive exclusion, patterns of plant invasions, relationships to species-abundance distributions, impact of scaling laws on vegetation classification, etc. With this Special Session, we want to provide a platform for presenting and discussing new results and ideas on scaling laws in plant biodiversity at any spatial scale (from square millimetres to the surface of the Earth) and for any habitat or biome. We welcome empirical studies, simulations, conceptual-theoretical contributions as well as presentations on databases and statistical tools to account for scaledependencies when analysing data diversity data across spatial scales.
Special Session 10 organised by EDGG

Patterns, drivers, and conservation opportunities of grassland biodiversity

Didem Ambarlı, Riccardo Guarino, Alla Aleksanyan \& Péter Török

Grasslands cover nearly $30 \%$ of all terrestrial surface, including diverse habitat types ranging from wet muddy slacks in lowlands to harsh rocky habitats in alpine environments. Grasslands harbour an extremely rich biodiversity, which is comparable at small scale to the richness of Atlantic rain forests. Grasslands provide essential ecosystem services and goods and contributing by $70 \%$ to all agricultural lands sustain the livelihood around 2 billion people worldwide. Grasslands face multiple threats worldwide including area loss, altered management by intensification or the cessation of former management, which can be listed as most important drivers. Describing biodiversity patterns and understanding key processes sustaining grassland biodiversity is essential for an effective conservation and restoration. The Eurasian Dry Grassland Group (EDGG) is an official working group of the IAVS and aims to facilitate and coordinate grassland research and conservation in the Palaearctic Biogeographic Realm. With this special session we would like to draw attention to the latest advancements in grassland research, and facilitate the scientific communication of researchers working with different types of grasslands worldwide. 


\section{Excursions}

Many of the pre-, mid- and post-symposium excursions have a strong grassland focus:

\section{Pre-symposium excursion 10-14 July 2019}

Harz and Kyffhäuser

Helge Bruelheide \& Ute Jandt

Organised by two long-standing EDGG members, this excursion will lead to the southeast of Bremen to the northermost mountain range in Germany that reaches the timber line (Harz) and to the Central German dry area in its rain shadow (Kyffhäuser and surroundings). A wide array of different grassland communities will be shown, in particular Violion caninae, Polygono-Trisetion, Bromion erecti, Festucion valesiacae, Cirsio-Brachypodion, Toninion, Geranion sanguinei as well as communities of heavy metal soils and rocky outcrops. Besides that, the study region also has nice forests and mires.

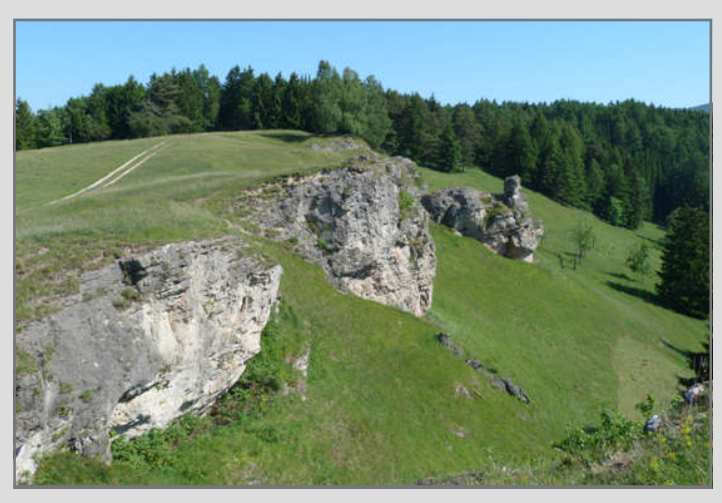

Calcareous grassland and rock vegetation, PreHarz. Photo: M. Diekmann.

\section{Mid-symposium excursions 17 July 2019}

The symposium week is interrupted on Wednesday by one-day excursions in the closer surroundings of Bremen. Eight attractive choices are available, from "Plant diversity in open cultural landscapes in Bremen" to "Heathlands and forests in the Lüneburger Heide".

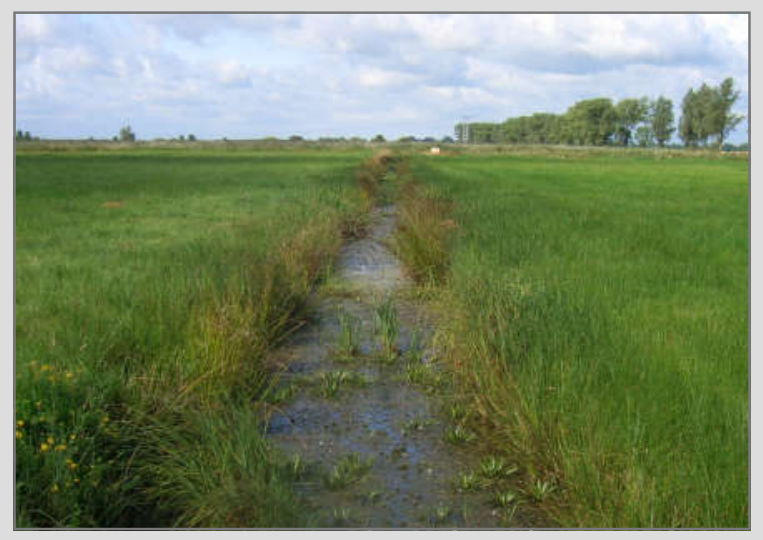

Ditch with Stratiotes aloides in a wet grassland near Bremen. Photo: M. Diekmann.

\section{Prices}

For IAVS members the conference fee (early bird) is 490 EUR, for students who are IAVS members even only 290 EUR, while non-IAVS members pay 580 EUR and 370 EUR, respectively. If you plan to attend, it is in any case worth to join IAVS because the annual fee is only 27 USD (regular) and 14 USD (students), i.e. much less than the differences in conference fees. Moreover, IAVS membership is completely free for many countries: http://iavs.org/ Membership/Financial-Support.aspx. Moreover, students and other people with low income who are IAVS members can apply for travel grants to cover their conference fees.

Further details: http://iavs.org/2019-Annual-Symposium/ Registration.aspx

\section{Post-symposium excursion 20-25 July 2019 \\ Wadden Sea Islands}

Maike Isermann

This excursion is conducted on two East Frisian islands (Baltrum and Spiekeroog) in one of the Wadden Sea National Parks. The vegetation types studied mainly belong to grasslands sensu lato, namely Therosalicornietea, Juncetea maritimi, Ammophiletea, Koelerio-Corynephoretea, IsoëtoNanojuncetea and Scheuchzerio-Caricetea.

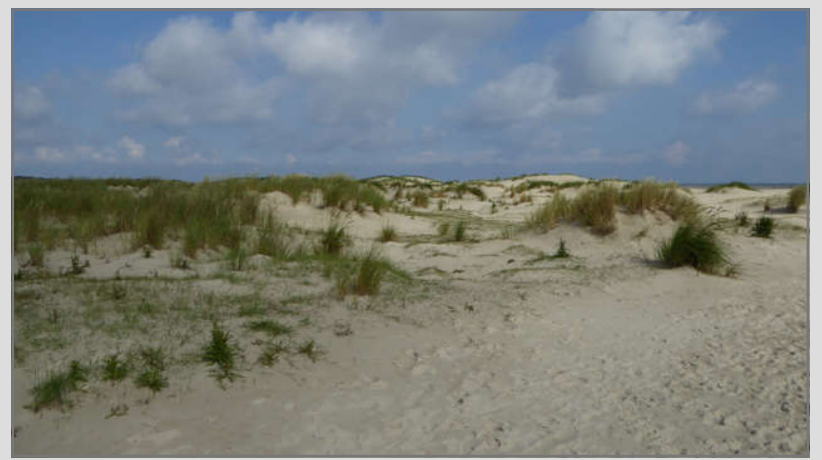

Dune grasslands on a Wadden Sea island (c). Photo: M. Diekmann.

\section{Important dates}

- 24 March 2019: Deadline for abstract submission

- 24 March 2019: Deadline for IAVS travel grant applications

- 10 May 2019: Deadline for early bird registration with reduced fees

- 25 June 2019: Deadline for standard registration

Jürgen Dengler (juergen.dengler@zhaw.ch) Alla Aleksanyan (alla.alexanyan@gmail.com) Iwona Dembicz (i.dembicz@gmail.com) Péter Török (molinia@gmail.com) 


\title{
Scientific Report
}

\section{Fire in the protected areas of Eastern Ukraine}

\author{
Olexiy Vasyliuk ${ }^{1,2^{*}}$, Grygoriy Kolomytsev ${ }^{1,2}$ \& Tatiana Sapsai $^{1}$
}

\author{
${ }^{1}$ Ukrainian Nature Conservation Group, Gogol str., 40, 08600 Vasylkiv, \\ Ukraine; vasyliuk@gmail.com (O. Vasyliuk), g.kolomytsev@gmail.com (G. \\ Kolomytsev), tatianamotsak30@gmail.com (T. Sapsai)
}

\author{
${ }^{2}$ Schmalhausen Institute of Zoology, NAS of Ukraine, B. Khmelnytskogo str., \\ 15, 01601 Kyiv, Ukraine. \\ *) Corresponding author: vasyliuk@gmail.com
}

Palaearctic Grasslands 41 (2019): 26-30

Abstract: In this study, we perform analysis of the spatial extent of the pyrogenic impact on steppe nature reserves in Donetsk and Luhansk regions during 2007-2016. The interest of researchers in remote investigation of steppe fires has increased significantly in recent years due to Ukraine's loss of control over a part of the territory of both regions because of the armed incursion and occupation of the territory from 2014 until the present. The number of fires within the anti-terrorist operation (ATO) zone detected by remote sensing in 2014 was 14.1 times higher than in 2013. Our study shows that during 2015-2016 more than $50 \%$ of steppe areas were affected by pyrogenic impacts. During 2007-2016, fires took place in the vast majority of steppe sites; only small patches of steppe territories remained unaffected.

Keywords: fire; nature reserve; protected area; pyrogenic impact; steppe; Ukraine.

Abbreviations: $\mathrm{ATO}=$ anti-terrorist operation; NRF = Nature Reserve Fund; PA = protected area.

Submitted: 10 May 2018; first decision 22 May 2018; accepted: 27 November 2018

Scientific Editor: Atushi Ushimaru

Linguistic Editor: Paul Goriup

\section{Introduction}

Luhansk and Donetsk regions are located in the south-east of Ukraine. These regions are the most favourable for the development of steppe habitats since the whole area lies within the steppe climatic zone. As a result, the share of natural and semi-natural steppe landscapes in the regions is the largest in Ukraine. Within the Donetsk region, the area of steppe landscapes is about $2,140 \mathrm{~km}^{2}$, while in Luhansk it is $5,113 \mathrm{~km}^{2}$, which is $8.04 \%$ and $19.16 \%$ of the regions' areas respectively (Kolomytsev \& Vasyliuk 2013).

The natural areas of the two regions mainly consist of steppe ecosystems: the central part of Donetsk and the south part of Luhansk regions holds the rocky steppes of the Donetsk ridge, while the northern part of Luhansk region supports steppe vegetation on surface exposures of chalk. The south of Donetsk region is occupied by the plains of black soil steppes bordering the Azov Sea.

From west to east, the region is intersected by the complex interzonal biotopes of the Siversky Donets river valley. This river forms a wide floodplain, occupied by meadow and forest vegetation, as well as sand arenas, which form partially preserved natural sandy steppes. These natural complexes should receive priority protection within the steppe zone biotopes of Ukraine.

However, much of the steppe area is not protected. For example, in Luhansk region, only $238 \mathrm{~km}^{2}$ of the steppe zone are covered by the Nature Reserve Fund (NRF, Vasyliuk et al. 2012), which is about $29 \%$ of the region's pro- tected territory, but it is only $4.65 \%$ of the steppe area located in the region. The amount of steppe conserved in Donetsk region is likely to be even smaller. The overall NRF within these territories covers only a small part of the natural and semi-natural steppe landscapes. Nevertheless, because of the poor environmental protection regime, negative impacts (such as pyrogenic impacts) affect the steppe areas inside the NRF as well as surrounding areas.

According to the results of our preliminary study of remote sensing data concerning the role of military actions on increasing the number of fires in natural vegetation (Kolomytsev et al. 2014), we found that just during the period from 1 July to 30 September 2014 in the ATO zone 2901 incidents of fires were detected. Thus, the number of fires in 2014 was 14.1 times higher than in 2013 (208 incidents of fires), and 5.2 and 5.9 times greater than during 2012 and 2011 (respectively, 566 and 501 cases of fires). Although in 2014 there was a higher density of fires both within and outside the ATO zone, the general distribution of fires remained similar and can be ascribed to traditional burning of crop stubble after the harvest period. The main reason for the higher number of fires was their unrestricted spread across the territory because of the absence of fire-prevention measures in the occupied territory. Between 1 July and 30 September 2014, fire damaged around $18 \%$ of the forest area within the ATO zone $(12.19 \%$ of the total area of the fires) and $23.19 \%$ of the steppe area within the ATO zone $(38.29 \%$ of the total area of fires; Vasyliuk et al. 2015). Previous studies also show the impor- 
tance of hostilities in increasing pyrogenic impacts on steppe ecosystems (Kuksyn \& Kreindlyn 2014).

Steppe fires are having unkown impacts on the conservation status of steppe ecosystems within the NRF owing to the lack of effective mechanisms for controlling them, auto -ignition of vegetation, and poor monitoring of the state of NRF territories: in Ukraine, special administrations are present only in the largest 100 protected areas, out of 8,300 sites. In the past, pyrogenesis was one of the main factors in the formation of open grassy ecosystems (Tyshkov 2005). Today, in most cases it has become the cause of their degradation. On the one hand, regular burning leads to the gradual deterioration of steppe biotopes: loss of biodiversity, the appearance of more resistant invasive species and the loss of organic matter in the soil (Anylova 2012). On the other hand, due to the lack of grazing and the consequent litter accumulation, "hot" fires lead to a more extensive reduction in the number of species present on the site (Lysenko 2008). Grassland management through controlled burns, which would be conducive to the sustainable maintenance of steppes, and which has been effectively introduced in other countries (Myers 2006), is currently not practised in Ukraine.

In our study, which covers steppe fires in all NRF sites in Donetsk and Luhansk regions, we sought to detect the incidence of such fires and assess the extent to which they affected biodiversity the NRF. Up to now, actual information on the influence of fires on steppes in east Ukraine was known only from the publications by staff of the Luhansk Nature Reserve (Borovyk 2004, 2009, 2014) and the Ukrainian Steppe Nature Reserve (Tymoshenkov \& Tymoshenkova 2007; Lymanskyi 2011, 2014) concerning fires in their territories. Our research aimed to identify the locations of pyrogenic impacts in the NRF of eastern regions of Ukraine, as well as identify areas that most needed measures to control ignition.

\section{Materials and methods}

An important task of our study was to locate ignitions and determine the spatial extent of affected areas. However, the point data available for us did not contain complete information on the area burned by a fire. However, we used the estimation of fire-affected areas according to the resource www.fires.kosmosnimky.ru, which extrapolates data and visualizes burned areas in the form of polygons. Taking into account the burned area determined by this resource, we calculated the original radius of the ignition field necessary for the formation of a particular polygon. Owing to the massive overlaps of the ignition polygons, we took the average radius of spread from the fire source (1712 m, n = 403), and used this number for spatial analysis of the burned area. After generating appropriate buffers around the fire points, we excluded settlements and rivers. Such a spatial model does not claim to be precise in detail, but we found it sufficient to determine the trends and general state of the overall pyrogenic impact on the NRF. A spatial analysis algorithm was implemented using
ArcGIS software based on spatial layers of administrative borders, settlements, and steppe areas. The algorithm we applied included the following steps:

1. Applying a buffer around the fixed fire points with the above defined radius of $1712 \mathrm{~m}$. For each year (20072016), a separate polygonal layer was created. We derived this data from NASA datasets (NASA 2018).

2. Applying interference in the spread of fires, including settlements and the Siversky Donets river.

3. Separation of spatial objects and removal of isolated areas outside obstacles.

4. Aggregation of polygonal objects.

5. Identification of burned steppes.

6. Determination of the area and administrative units of the steppe areas derived from the steppe cadaster of Ukraine, developed by Kolomytsev \& Vasyliuk (2013): import and data processing.

\section{Results and discussion}

In Donetsk region, we identified 124 NRF sites of which 73 fully or partially included steppe ecosystems. Moreover, 54 of the protected areas (PAs) lie within the zone of military conflict (45 of them are steppe PAs). Considering their distribution, we assume that most of the steppe areas within the NRF of Donetsk region are presently located in the occupied territories (ATO zone).

Over 10 years, firefighting was detected by means of remote sensing (Fig. 1) in 40 NRF sites, of which 22 are in the ATO zone, including 20 that are steppes.

Of the 18 NRF sites affected by fire outside the ATO zone, 10 are steppes (out of 29 existing steppe sites outside the ATO zone). Detailed information about the fires detected within NRF sites in Donetsk region from 2007 to 2016 is presented in Table 1.

There are 183 NRF sites in Luhansk region, of which 108 fully or partially include steppe ecosystems. This number includes $81 \mathrm{NRF}$ sites presently located within the ATO zone, of which 51 are steppes. Giventhis distribution of sites, it can be seen that half of all steppe sites are in the ATO zone, and also that the steppe sites make up $61 \%$ of all NRF sites in the ATO zone.

Between 2007 and 2016, we detected fires in 66 NRF sites in Luhansk region (Fig. 1, Fig. 2), of which 27 were in the ATO zone. Out of the latter sites, 24 are steppes meaning that almost all of the affected areas in the ATO zone of Luhansk region are steppe ecosystems. The 39 non-ATO NRF sites struck by the fire included 31 are steppes (out of 57 existing steppes outside the ATO zone). Thus, the NRF steppe sites most affected by fire are those within the ATO zone (Table 2).

The spatial analysis and assessment of fires occurring within the steppes of Eastern Ukraine shows the widespread character of pyrogenic effects: during 2015-2016 we detected burning of more than $50 \%$ of steppe areas 


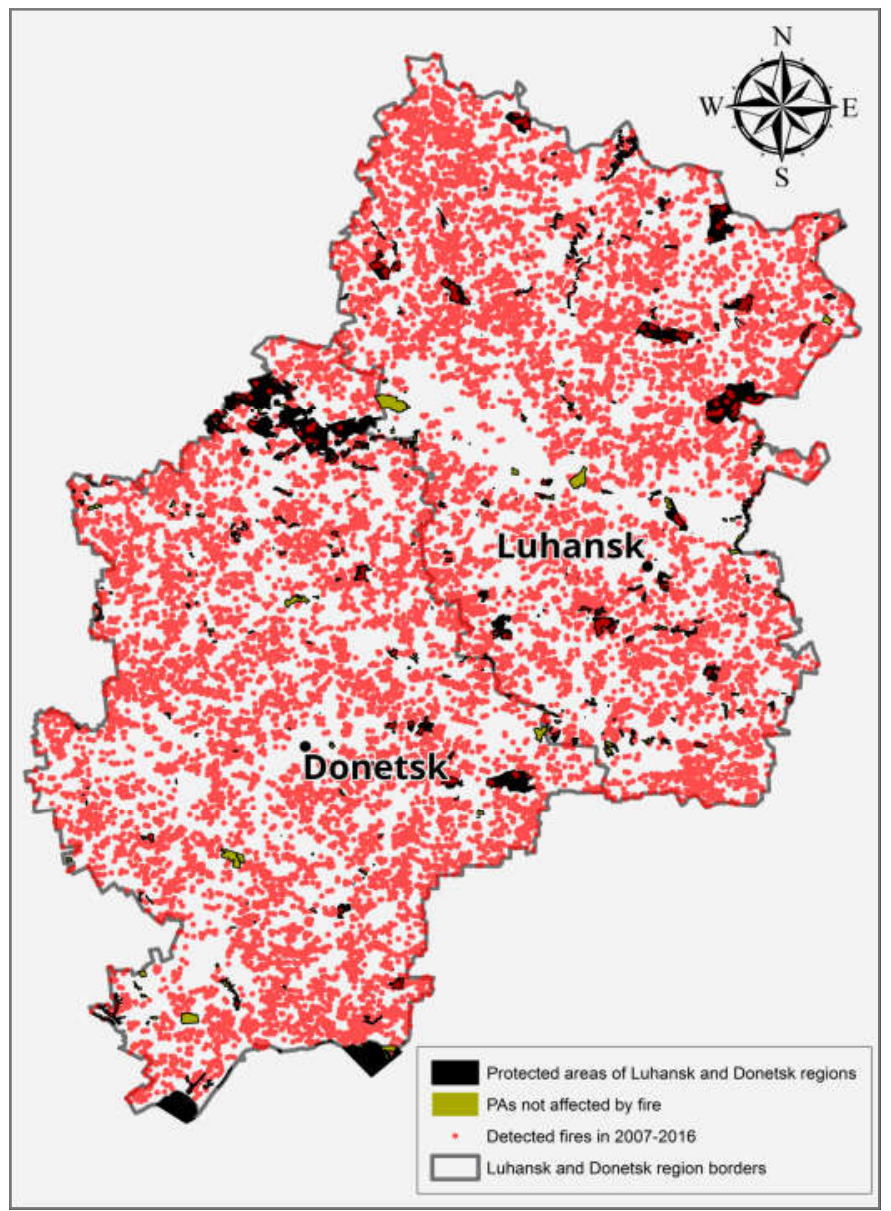

Fig. 1. Distribution of detected fires and protected areas in the Luhansk and Donetsk regions. Black areas indicate protected areas affected by fires.

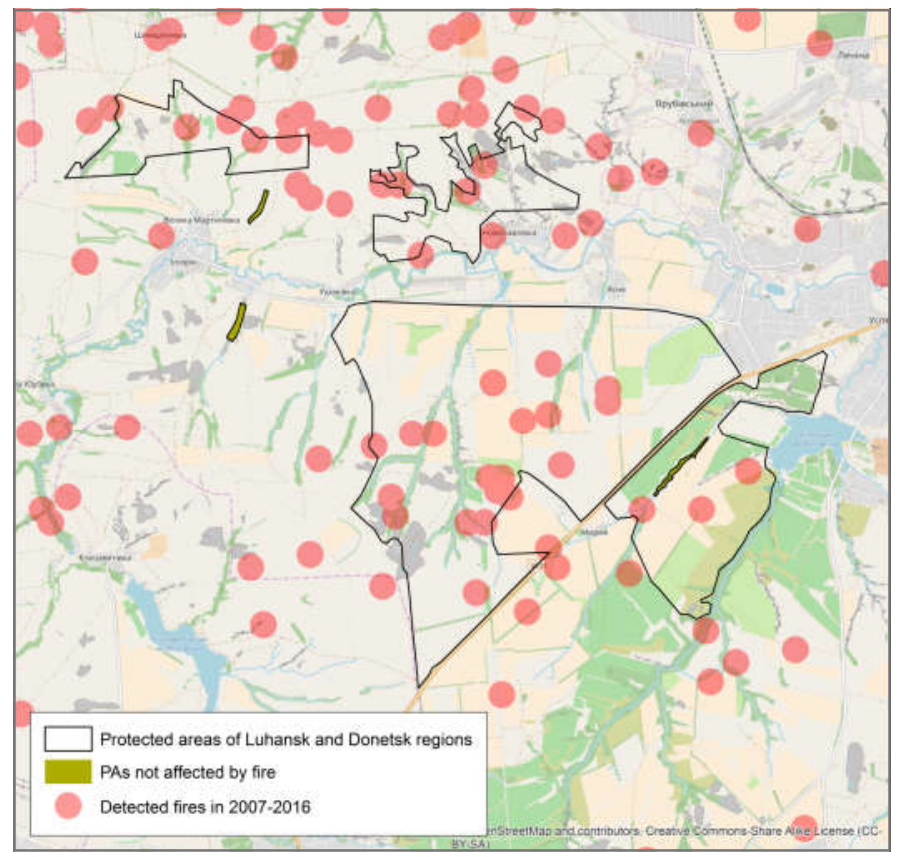

Fig. 2. Example of fires within protected areas, Luhansk region. within the studied area. Moreover, the study did not take into account the fact that a number of sites, according to extrapolation of fire-affected sites, burned twice or more each year. During the entire period covered in the study, fires took place in the vast majority of steppes; only the smallest patches of the steppe sites remained unburned (Figs. 1 and 2). The full impact of fire on steppe areas still needs to be elucidated in detail, in order to define spatial rules of the occurrence of fires.

\section{Author contributions}

V.O. planned the research and wrote the paper, K.G. designed the methodological approach and conducted the spatial analysis of areas affected by pyrogenic impact, while all authors critically revised the manuscript.

\section{References}

Anylova, L.V. 2012. Postpyrohennaia transformatsyia pochv stepnoi zony Orenburhskoho Preduralia [Post-pyrogenic transformation of soils in the steppe zone of the Orenburg Pre-Urals]. Stepy Severnoi Evrazyi 6: 47-49. [in Russian]

Borovyk, L.P. 2004. Vlyianye pyrohennoho faktora na populiatsyy dernovynnikh zlakova [Influence of the pyrogenic factor on the population of arable cereals]. Materialy naukovopraktychnoi konferentsii "Zberezhennia bioriznomanitnosti na pivdenomu skhodi Ukrainy»: 17. Donetsk, UA. [in Russian]

Borovyk, L.P. 2009. Postpyrohennaia dynamyka rastytelnikh soobshchestv Streltsovskoi stepi [Post-pyrogenic dynamics of plant communities of 'Streltsovskaya steppe' reserve]. Zbirka tez dopovidei mizhnarodnoi konferentsii V-yi botanichni chytannia pamiati I.K. Pachoskoho: 101. Kherson, UA. [in Russian]

Borovyk, L. 2014. Posledstvyia voennoho konflykta dlia Luhanskoho pryrodnoho zapovednykaa [Consequences of the military conflict for the Lugansk natural reserve]. Stepnoi Biulleten 42: 34-35. [in Russian]

Kolomytsev, G. \& Vasyliuk, O. 2013. Prostorovyi rozpodil stepovykh ekosystem na skhodi Ukrainy [Spatial distribution of steppe ecosystems in eastern Ukraine]. Visnyk Natsionalnoho Naukovo-pryrodnychoho Muzeiu 11: 87-93. [in Ukrainian]

Kolomytsev, G., Shyriaieva, D. \& Vasyliuk, O. 2014. The impact of fires in the anti-terrorist operation zone in Ukraine: assessment using RS and GIS data. In: Babiarz, A. \& Byrska, M. (eds.) Materiały konferencyjne GIS DZIŚ (Kraków, 17 - 18 listopada 2014), pp. 42-43. Krakow, PL.

Kuksyn, H.V. \& Kreindlyn, M.L. 2014. Stepnye pozhary: profylaktyka, tushenye, pravovye voprosy. Metodycheskye rekomendatsyy dlia sotrudnykov osobo okhraniaemykh pryrodnykh terrytoryi [Steppe fires: prevention, quenching, legal issues. Methodical recommendations for protected areas]. Center of Wild Nature Protection, Moscow, RU. [in Russian]

Lymanskyi, S.V. 2011. Zapovednyk "Melovaia flora" pered uhrozoi pozhara [Reserve "Melovaya Flora" facing fire threats]. Stepnoi Biulleten 32: 58-61. [in Russian]

Lymanskyi, S.V. 2014. Voennye deistvyia na terrytoryy zapovednyka «Melovaya flora» [Military actions on the territory of the reserve "Melovaya flora"]. Stepnoi Biulleten 42: 34-35. [in Russian]

Lysenko, H. 2008. Pyrohennie aspekty abyotycheskoi rehuliatsyy stepnikh rezervatnikh ekosystem [Pyrogenic aspects of the abiotic regulation of steppe reserve ecosystems]. Ekolohiia ta Noosferolohiia 19: 143-147. [in Russian]

Myers, R.L. 2006. Living with fire - sustaining ecosystems \& livelihoods through integrated fire management. Global Fire Initiative, Tallahassee, US. 
Table 1. Number of fire events detected within the NRF sites of Donetsk region, 2007-2016.

\begin{tabular}{|c|c|c|c|c|c|c|c|c|c|c|}
\hline NAME & 2007 & 2008 & 2009 & 2010 & 2011 & 2012 & 2013 & 2014 & 2015 & 2016 \\
\hline Reserve "Mayatska Dacha" & 1 & 0 & 2 & 0 & 0 & 0 & 0 & 0 & 0 & 0 \\
\hline Reserve "Balka Sukha" * & 0 & 1 & 0 & 0 & 0 & 0 & 1 & 1 & 0 & 0 \\
\hline Reserve "Ridkodubia" & 1 & 0 & 0 & 0 & 0 & 0 & 0 & 0 & 0 & 0 \\
\hline Reserve "Stupki-Golubovsky" & 0 & 0 & 0 & 0 & 0 & 0 & 1 & 0 & 0 & 0 \\
\hline Reserve "Balka Orlynska" & 0 & 0 & 0 & 0 & 0 & 0 & 0 & 1 & 1 & 0 \\
\hline Reserve "Verkhnesamarsky" & 0 & 0 & 0 & 0 & 0 & 0 & 0 & 0 & 0 & 1 \\
\hline Reserve "Hectova balka " & 0 & 0 & 0 & 1 & 0 & 0 & 0 & 2 & 0 & 0 \\
\hline Reserve "Zoryansky step" * & 0 & 1 & 0 & 0 & 0 & 0 & 0 & 0 & 1 & 0 \\
\hline Reserve "Kovil near the village of Grigorivka" & 1 & 0 & 0 & 0 & 1 & 0 & 0 & 0 & 0 & 0 \\
\hline Reserve "Kohane" & 0 & 0 & 1 & 0 & 0 & 0 & 0 & 0 & 0 & 0 \\
\hline Reserve "Cretaceous vegetation near the village of Kirov" & 1 & 0 & 1 & 2 & 0 & 1 & 0 & 0 & 0 & 0 \\
\hline Reserve "Palimbia" & 0 & 0 & 0 & 0 & 0 & 0 & 0 & 0 & 0 & 1 \\
\hline Reserve "Pristenskoe" * & 0 & 0 & 0 & 0 & 0 & 0 & 0 & 0 & 1 & 0 \\
\hline Reserve "Uvochishche Obushok" * & 1 & 0 & 0 & 0 & 0 & 0 & 0 & 1 & 0 & 0 \\
\hline Reserve "Razdolnensky" * & 0 & 0 & 0 & 0 & 0 & 0 & 0 & 1 & 0 & 0 \\
\hline Reserve "Kruglik" * & 0 & 0 & 1 & 0 & 0 & 0 & 0 & 0 & 0 & 0 \\
\hline Protected tract "Mariupol Forest Cottage" $*$ & 0 & 0 & 0 & 0 & 0 & 0 & 0 & 1 & 0 & 0 \\
\hline Protected tract "Shyroky lis" & 0 & 1 & 0 & 0 & 0 & 0 & 0 & 0 & 0 & 0 \\
\hline Protected tract of local significance "Myrne pole" & 0 & 1 & 0 & 0 & 0 & 0 & 0 & 0 & 1 & 0 \\
\hline Reserve "Oak plantations" & 2 & 1 & 0 & 0 & 0 & 0 & 0 & 0 & 0 & 0 \\
\hline Forest reserve "Artemivsk garden-dendrological plantings" & 1 & 1 & 4 & 2 & 2 & 1 & 3 & 5 & 0 & 4 \\
\hline Forest reserve "Balka Skeleva" * & 0 & 0 & 0 & 0 & 2 & 1 & 0 & 0 & 0 & 0 \\
\hline Forest reserve "Shchucha Zavod" & 0 & 0 & 0 & 0 & 0 & 0 & 0 & 1 & 1 & 0 \\
\hline Forest reserve "Berdiansky" * & 0 & 4 & 0 & 0 & 0 & 0 & 0 & 5 & 0 & 0 \\
\hline Forest reserve "Urochysche Leontievo-Bayraktske" * & 0 & 0 & 3 & 0 & 0 & 0 & 0 & 0 & 1 & 0 \\
\hline Forest reserve "Urochysche Ploske" * & 0 & 0 & 0 & 0 & 1 & 0 & 0 & 0 & 0 & 0 \\
\hline Forest reserve "Urochysche Sofiivske" * & 0 & 2 & 0 & 0 & 0 & 0 & 0 & 0 & 0 & 0 \\
\hline National Nature Park "Meotida" * & 9 & 8 & 5 & 2 & 6 & 2 & 2 & 10 & 13 & 6 \\
\hline National Nature Park "Sviati gory" * & 16 & 5 & 12 & 0 & 4 & 1 & 2 & 9 & 5 & 5 \\
\hline Forest reserve "Priazovsky chapelnyk" * & 1 & 0 & 1 & 0 & 1 & 0 & 0 & 1 & 3 & 0 \\
\hline $\begin{array}{l}\text { Ukrainian Steppe Nature Reserve "Kalmiuski" * } \\
\end{array}$ & 0 & 0 & 0 & 2 & 0 & 0 & 0 & 5 & 0 & 1 \\
\hline Ukrainian Steppe Nature Reserve "Kreydiana flora" * & 0 & 0 & 1 & 0 & 0 & 0 & 0 & 2 & 0 & 0 \\
\hline Ukrainian Steppe Nature Reserve "Khomutovsky Steppe" * & 1 & 4 & 0 & 0 & 0 & 0 & 0 & 0 & 0 & 0 \\
\hline Regional Landscape Park "Kleban-Byk" * & 0 & 0 & 0 & 0 & 0 & 0 & 2 & 2 & 0 & 0 \\
\hline Regional Landscape Park "Slavic Resort" * & 1 & 0 & 0 & 0 & 0 & 0 & 0 & 0 & 0 & 0 \\
\hline Regional Landscape Park "Donetsk Ridge" * & 2 & 0 & 0 & 2 & 0 & 3 & 0 & 22 & 0 & 0 \\
\hline Regional Landscape Park "Zuyevsky" * & 1 & 1 & 1 & 2 & 2 & 0 & 0 & 4 & 0 & 0 \\
\hline Regional Landscape Park "Kramatorsky" * & 2 & 1 & 3 & 0 & 3 & 1 & 0 & 3 & 1 & 0 \\
\hline Regional Landscape Park "Polovetsky Steppe" & 2 & 1 & 0 & 0 & 2 & 0 & 0 & 0 & 5 & 0 \\
\hline Total number of detected fires & 43 & 32 & 35 & 13 & 24 & 10 & 11 & 76 & 33 & 18 \\
\hline
\end{tabular}

This table and table 2 does not include NRF sites that were not affected by fires during 2007-2016. Selected cells indicate the period before the NRF sites were established.

* - NRF sites within the current or former ATO zone.

Table 2. Number of fire events detected within the NRF sites of Luhansk region, 2007-2016.

\section{NAME}

Zoological Reserve "Illirijsky"*

Forest Reserve "Vrubivsky"

Forest Reserve "Novogannivsky"

Forest Reserve "Kamjansky"

Forest Reserve "Balakirivsky"

Forest Reserve "Vedmezhanska"

Reserve "Kosharsky"*

Forest Reserve "Barsucha Balka"*

Reserve "Ganivsy lis"

Reserve "Velikocky"

Reserve "Bilorichensky"

Forest Reserve "Stepovi rozlogi"*

Forest Reserve "Lugansky"*

Forest Reserve "Pershozvanivsky"*

Reserve "Novorozsoshansky"

Reserve "Novochervonensky"

\begin{tabular}{cccccccccc}
2007 & 2008 & 2009 & $\mathbf{2 0 1 0}$ & $\mathbf{2 0 1 1}$ & $\mathbf{2 0 1 2}$ & $\mathbf{2 0 1 3}$ & $\mathbf{2 0 1 4}$ & $\mathbf{2 0 1 5}$ & $\mathbf{2 0 1 6}$ \\
\hline 4 & 11 & 3 & 3 & 0 & 2 & 0 & 3 & 4 & 2 \\
0 & 1 & 0 & 0 & 0 & 0 & 0 & 0 & 0 & 0 \\
0 & 0 & 0 & 1 & 0 & 0 & 0 & 0 & 0 & 0 \\
0 & 0 & 0 & 2 & 1 & 0 & 0 & 0 & 1 & 0 \\
\hline 0 & 0 & 1 & 0 & 0 & 0 & 0 & 0 & 0 & 0 \\
2 & 5 & 0 & 7 & 0 & 0 & 0 & 8 & 8 & 0 \\
\hline 1 & 0 & 0 & 0 & 0 & 0 & 0 & 0 & 2 & 0 \\
0 & 0 & 0 & 0 & 0 & 0 & 0 & 2 & 0 & 0 \\
\hline 0 & 0 & 1 & 1 & 0 & 0 & 0 & 0 & 0 & 0 \\
0 & 0 & 1 & 0 & 0 & 0 & 0 & 2 & 0 & 0 \\
\hline 0 & 3 & 0 & 3 & 1 & 2 & 0 & 4 & 2 & 0 \\
\hline 0 & 1 & 0 & 0 & 2 & 0 & 0 & 0 & 1 & 0 \\
\hline 0 & 0 & 1 & 0 & 0 & 0 & 0 & 3 & 0 & 0 \\
0 & 2 & 0 & 0 & 0 & 0 & 0 & 0 & 0 & 0 \\
\hline 1 & 1 & 0 & 0 & 0 & 0 & 0 & 0 & 0 & 0 \\
\hline 1 & 0 & 0 & 0 & 0 & 0 & 0 & 1 & 0 & 0 \\
\hline
\end{tabular}


Table 2. Continuation

\begin{tabular}{|c|c|c|c|c|c|c|c|c|c|c|}
\hline NAME & 2007 & 2008 & 2009 & 2010 & 2011 & 2012 & 2013 & 2014 & 2015 & 2016 \\
\hline Forest Reserve "Nagolny krjazh"* & 1 & 0 & 0 & 6 & 0 & 0 & 0 & 1 & 2 & 0 \\
\hline Forest Reserve "Kruzhilivsky"* & 0 & 1 & 0 & 0 & 0 & 0 & 0 & 0 & 0 & 0 \\
\hline Zoological Reserve "Mistkivsky" & 6 & 4 & 1 & 0 & 0 & 0 & 0 & 6 & 5 & 0 \\
\hline Forest Reserve "Minyevska dibrova" & 0 & 1 & 0 & 0 & 0 & 0 & 0 & 0 & 0 & 0 \\
\hline Forest Reserve "Novozvanivsky"* & 1 & 0 & 0 & 0 & 0 & 0 & 0 & 2 & 0 & 0 \\
\hline Forest Reserve "Juskina river valley"* & 0 & 1 & 0 & 0 & 0 & 0 & 0 & 2 & 1 & 0 \\
\hline Forest Reserve "Orihova river valley"* & 0 & 1 & 0 & 1 & 0 & 0 & 0 & 1 & 0 & 0 \\
\hline Zoological Reserve "Urochishhe Murzine" & 0 & 0 & 0 & 0 & 0 & 0 & 0 & 0 & 1 & 1 \\
\hline Forest Reserve "Gorihivska Dibrova"* & 0 & 0 & 2 & 0 & 0 & 0 & 0 & 0 & 0 & 0 \\
\hline Reserve "Urochishhe Rozsohuvate" & 0 & 0 & 1 & 0 & 0 & 0 & 1 & 0 & 0 & 0 \\
\hline Forest Reserve "Urochishhe Skelevate" & 0 & 0 & 0 & 0 & 0 & 0 & 0 & 1 & 0 & 0 \\
\hline Forest Reserve "Shariv Kut"* & 0 & 0 & 0 & 0 & 0 & 0 & 0 & 1 & 2 & 0 \\
\hline Reserve "Lisnopoljanska" & 0 & 0 & 1 & 0 & 0 & 0 & 0 & 0 & 1 & 0 \\
\hline Reserve "Zarichna" & 0 & 0 & 1 & 0 & 0 & 0 & 0 & 0 & 0 & 0 \\
\hline Zoological Reserve "Goncharivsky" & 4 & 3 & 3 & 4 & 4 & 0 & 0 & 0 & 7 & 0 \\
\hline Reserve "Klenovij lis" & 0 & 1 & 2 & 0 & 0 & 0 & 0 & 0 & 0 & 1 \\
\hline Forest Reserve "Samsonivska zavod" & 0 & 1 & 0 & 0 & 0 & 0 & 0 & 0 & 0 & 0 \\
\hline Zoological Reserve "Lisova perlina" & 3 & 0 & 4 & 1 & 0 & 0 & 0 & 3 & 0 & 0 \\
\hline Entomologic Reserve "Krimsky"* & 0 & 0 & 1 & 0 & 0 & 0 & 0 & 0 & 0 & 0 \\
\hline Geologic Reserve "Krimska Dacha"* & 0 & 0 & 1 & 0 & 0 & 0 & 0 & 1 & 0 & 0 \\
\hline Reserve "Seleznivska balka"* & 0 & 0 & 0 & 0 & 0 & 0 & 0 & 1 & 0 & 0 \\
\hline Zoological Reserve "Perevalsky"* & 2 & 0 & 0 & 0 & 0 & 11 & 4 & 18 & 1 & 5 \\
\hline Protected Tract "Kiseleva balka"* & 0 & 0 & 0 & 0 & 0 & 1 & 0 & 0 & 0 & 0 \\
\hline Reserve "Grishino"* & 0 & 0 & 0 & 0 & 0 & 1 & 0 & 0 & 1 & 0 \\
\hline Forest Reserve "Krasnjanske vodoshovishhe"* & 1 & 0 & 0 & 1 & 0 & 0 & 0 & 4 & 4 & 0 \\
\hline Protected Tract "Pischane"* & 0 & 0 & 0 & 0 & 0 & 0 & 0 & 3 & 0 & 0 \\
\hline Reserve "Kanyshnyansky"* & 0 & 0 & 0 & 0 & 0 & 0 & 0 & 1 & 0 & 0 \\
\hline Reserve "Znamyany yar"* & 0 & 0 & 1 & 0 & 0 & 0 & 0 & 0 & 0 & 0 \\
\hline Reserve "Lisne"* & 0 & 0 & 0 & 1 & 0 & 0 & 0 & 2 & 1 & 0 \\
\hline Reserve "Kuryachy" & 0 & 0 & 0 & 0 & 0 & 0 & 0 & 0 & 1 & 0 \\
\hline Zoological Reserve "Balka berezova" & 3 & 6 & 0 & 0 & 0 & 0 & 0 & 0 & 5 & 0 \\
\hline Regioal Landscape Park “Bilovodsky" & 7 & 10 & 4 & 1 & 1 & 0 & 6 & 8 & 19 & 0 \\
\hline Zoological Reserve "Geraskivsky" & 1 & 3 & 2 & 1 & 1 & 0 & 0 & 2 & 3 & 0 \\
\hline Protected Tract "Kapitanivsky lis" & 0 & 0 & 0 & 1 & 0 & 0 & 0 & 0 & 2 & 0 \\
\hline Zoological Reserve "Yevsug-Stepove" & 6 & 1 & 4 & 1 & 1 & 3 & 2 & 9 & 3 & 0 \\
\hline Zoological Reserve "Geraskivsky" & 0 & 0 & 2 & 0 & 0 & 0 & 0 & 1 & 0 & 0 \\
\hline Luhansk Nature Reserve "Striltsivsky step" & 3 & 0 & 0 & 0 & 0 & 0 & 0 & 0 & 0 & 0 \\
\hline Luhansk Nature Reserve “Triohizbensky step" & 1 & 0 & 0 & 0 & 0 & 0 & 0 & 0 & 0 & 0 \\
\hline Luhansk Nature Reserve "Stanychno-Luhanske" & 5 & 0 & 1 & 0 & 0 & 0 & 0 & 0 & 14 & 1 \\
\hline Luhansk Nature Reserve "Provalsky step" & 0 & 1 & 4 & 0 & 0 & 4 & 0 & 8 & 0 & 0 \\
\hline Protected Tract "Bokovo-Platovo"* & 0 & 0 & 1 & 0 & 0 & 0 & 0 & 2 & 0 & 0 \\
\hline Zoological Reserve "Kononivske" & 10 & 17 & 2 & 3 & 4 & 0 & 3 & 4 & 1 & 0 \\
\hline Zoological Reserve "Terny" & 2 & 1 & 2 & 0 & 0 & 0 & 0 & 1 & 2 & 0 \\
\hline Zoological Reserve "Miluvatsky lyman" & 0 & 2 & 0 & 1 & 0 & 0 & 0 & 1 & 0 & 0 \\
\hline Forest Reserve "Bilolutsky" & 7 & 2 & 0 & 0 & 2 & 0 & 0 & 0 & 0 & 0 \\
\hline Forest Reserve "Novopskovsky" & 0 & 2 & 1 & 0 & 0 & 1 & 0 & 0 & 0 & 0 \\
\hline Reserve "Balka ploska" & 2 & 4 & 0 & 0 & 0 & 0 & 4 & 0 & 0 & 0 \\
\hline Reserve "Osynivska" & 3 & 1 & 1 & 0 & 0 & 3 & 0 & 6 & 4 & 0 \\
\hline Protected Tract "Moskovske" & 1 & 0 & 0 & 0 & 0 & 1 & 0 & 0 & 1 & 0 \\
\hline Total number of detected fires & 78 & 87 & 49 & 39 & 17 & 29 & 20 & 112 & 99 & 10 \\
\hline
\end{tabular}

NASA 2018. Earth observation data. URL: https:// earthdata.nasa.gov/earth-observation-data/ [accessed 30 July 2018]

Tymoshenkov, V.A. \& Tymoshenkova, V.V. 2007. Pozhary v Khomutovskoi stepy [The fires in the Khomutovsky steppe]. Stepnoi Biulleten 23-24: 27-32. [in Russian]

Tyshkov, A.A. 2005. Ohon y problemu byoraznoobrazyia: tematycheskyi obzor [Fire and biodiversity issues: a thematic review]. In: Studying and preserving the natural ecosystems of nature reserves in the forest-steppe zone: Materials of the international scientific-practical conference dedicated to the 70th anniversary of the Central Chernozem Nature Reserve: pp. 113-115. Central Chernozem Nature Reserve, Kursk, RU. URL: http://www.biodat.ru [accessed 30 July 2005]. [in Russian]

Vasyliuk, O., Balashov, I., Kryvokhyzha, M. \& Kolomytsev, G. 2012. Landshaftnyi sklad pryrodno-zapovidnoho fondu Luhanskoi oblasti [Landscape composition of the nature reserve fund of Lugansk region]. Zapovidna Sprava v Ukraini 1-2: 105-110. [in Ukrainian]

Vasyliuk, O., Nekrasova, O., Shyriaieva, D. \& Kolomytsev, G. 2015. A review of major impact factors of hostilities influencing biodiversity in eastern Ukraine (modeled on selected animal species). Vestnik Zoologii 49: 145-158. 


\section{Recent Publications of our Members}

In this section, the contents of which will also be made available via our homepage, we want to facilitate an overview of grassland-related publications throughout Eurasia and to improve their accessibility. You are invited to send lists of such papers from the last three years following the format below to Iwona Dembicz, iwodem@op.pl. We will include your email address so that readers can request a pdf. For authors who own full copyright, we can also post a pdf on the EDGG homepage.

\section{Classification of grasslands}

Biurrun, I., Bergmeier, E., Dengler, J., Jansen, F. \& Willner, W. 2019. Vegetation classification and its application are relevant globally. Phytocoenologia 49: 1-6.

Willner, W., Roleček, J., Korolyuk, A., Dengler, J., Chytrý, M., Janišová, M., Lengyel, A., Aćić, S., Becker, T., Ćuk, M., Demina, O., Jandt, U., Kącki, Z., Kuzemko, A., Kropf, M., Lebedeva, M., Semenishchenkov, Y., Šilc. U., Stančić, Z., Staudinger, M., Vassilev, K. \& Yamalov, S. 2019. Formalized classification of the semi-dry grasslands of central and eastern Europe. Preslia 91: 25-49.

\section{Conservation and restoration}

Wagner, M., Fagan, K.C., Jefferson, R.G., Marrs, R.H., Mortimer, S.R., Bullock, J.M. \& Pywell, R.F. 2019. Species indicators for naturally-regenerating and old calcareous grassland in southern England. Ecological Indicators 101: 804-812.

\section{Contact persons:}

Idoia Biurrun: idoia.biurrun@ehu.es Jürgen Dengler: juergen.dengler@uni-bayreuth.de Richard G. Jefferson: Richard.Jefferson@naturalengland.org.uk

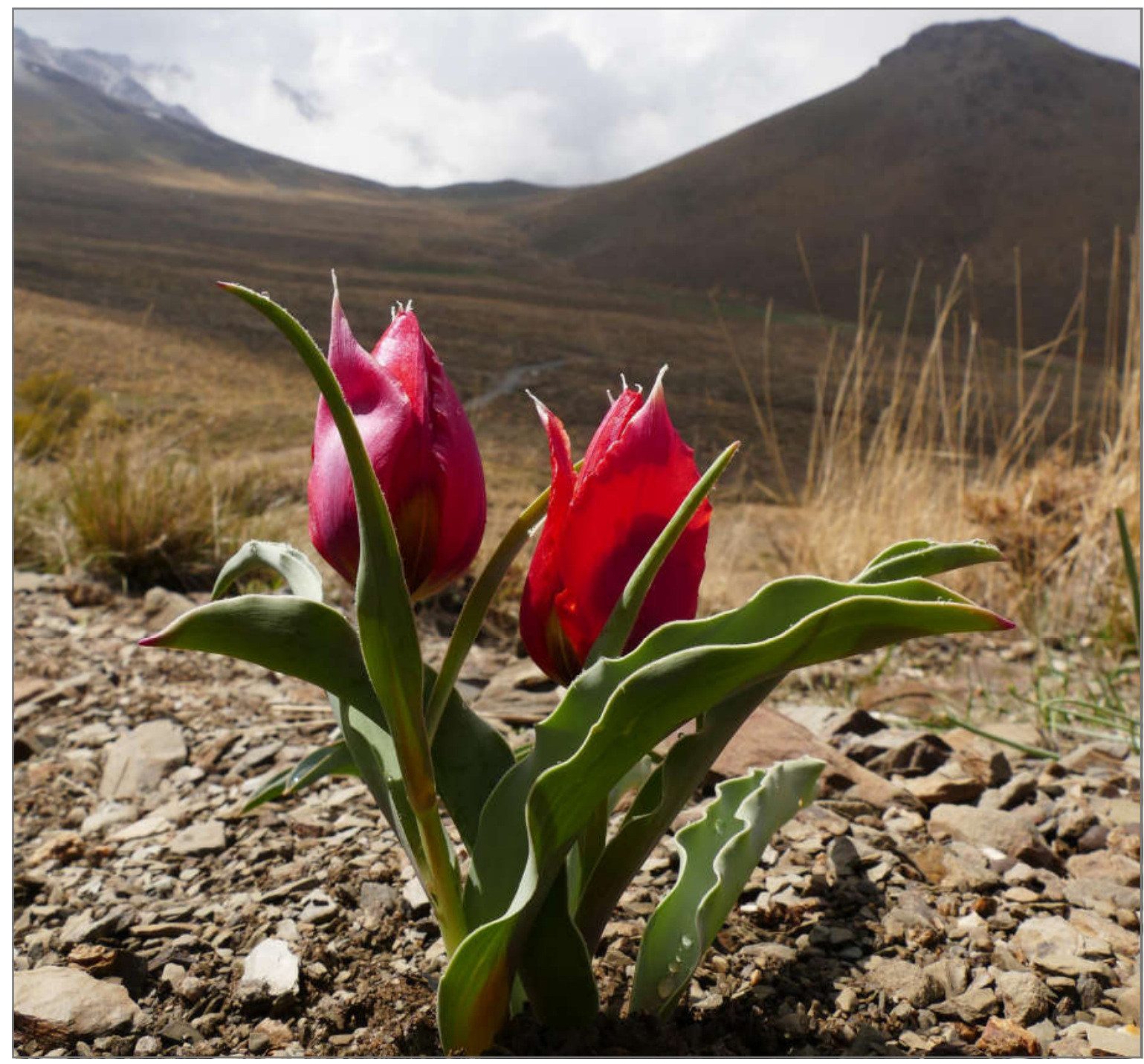

Tulipa systole in Golestankuh 2600 m a.s.I., Central Zagros, Iran. Photo: J. Noroozi. 


\section{Forthcoming Events}

32nd meeting of the GfÖ-Specialist Group Plant Population (PopBio)

23-25 May 2019 in Warsaw, Poland

\section{European Congress of Lepidopterology}

3-7 June 2019 at the University of Molise, Campobasso, Italy

Early registration deadline: March 15, 2019, abstract submission deadline: April 15, 2019.

Conference website: http://www.sel2019conference.com/

12th EDGG Field Workshop: Inneralpine dry valleys of Switzerland

11-19 May 2019, Switzerland

See details in this issue, on pp. 9-22.

16th Eurasian Grassland Conference (EGC)

29 May - 5 June 2019 in Graz, Austria and Maribor, Slovenia See details in Palaearctic Grasslands 40, pp. 11-21.

!New deadlines at the end of this page

Conference website: https://edgg.org/egc2019

13th EDGG Field Workshop: Grasslands of Armenia along the elevational gradient

26 June -7 July 2019, Armenia

See details in this issue, on pp. 9-22.

10th International Association for Landscape Ecology (IALE) World Congress

1-5 July 2019 in Milan, Italy

Conference website: http://www.iale2019.unimib.it/

62nd Annual Symposium of International Association for Vegetation Science (IAVS)

14-19 July 2019 in Bremen, Germany

Conference website: http://iavs.org/2019-AnnualSymposium/Home.aspx

See details in this issue, on pp. 23-25
SCB's 29th International Congress for Conservation Biology (ICCB 2019)

21-25 July 2019 in Kuala Lumpur, Malaysia

Conference website: https://conbio.org/mini-sites/iccb2019/

28th Workshop of Vegetation European Survey (EVS)

2-6 September 2019 in Madrid, Spain

20th European Congress of Herpetology

2-6 September 2019 in Milan, Italy

Conference website: http://seh-congress-2019.unipv.it/

49th Annual Meeting of the Ecological Society of Germany, Austria and Switzerland (GfÖ)

9-13 September 2019 in Münster, Germany

Conference website: https://www.gfoe-conference.de/

8th World Conference on Ecological Restoration

22-27 September 2019 in Cape Town, South Africa

Conference website: https://ser2019.org/

"Lost world" in biodiversity studies: focus at the Earth's blank spaces

23-27 September 2019, Vladivostok, Russia

Conference website: http://www.geobotanica.ru/ symposium 2019

\section{World Conference of the Ecosystem Service Partnership}

21-25 October 2019 in Hannover, Germany, with UFZ/iDiv as co-organisers

Conference website: https://www.espconference.org/esp10

Meeting of the FAO-CIHEAM Networks on Sheep and Goats and Mediterranean Pastures

23-25 October 2019 in Meknes, Morocco

Abstract submission deadline: 27 February 2019.

Full text submission deadline: 15 May 2019.

Conference website: http://networks.iamz.ciheam.org/ meknes2019/en/index.php

Some of the deadlines for application to the 16th European Grassland Conference have been extended! Because of the rather short period between finishing the conference homepage and the deadlines, we decided to extend some of them. There are even still a few places available for the post-conference excursion. New deadlines:

Early Bird registration deadline -15 March Late registration deadline -29 March Abstract submission deadline - 29 March Acceptance of abstracts and type of presentation $\mathbf{- 2 6}$ April Post-conference excursion application - 22 March Travel grant application deadline - $\mathbf{1 5}$ March Travel grant allocation - 12 April 


\section{EDGG}

Grass|and]

research and conservation
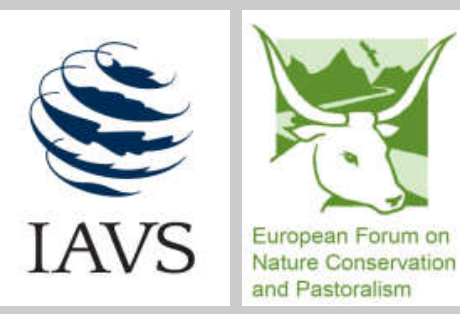

EDGG on the web:

http://www.edgg.org

EDGG in Facebook:

https://www.facebook.com/groups/938367279561202

EDGG on the ResearchGate

https://www.researchgate.net/project/EDGG-Eurasian-

DryGrassland-Group

The Eurasian Dry Grassland Group (EDGG), founded in 2008, is a working group of the International Association for Vegetation Science (IAVS) and member of the European Forum on Nature Conservation and Pastoralism (EFNCP). On 5 March 2019, it had 1339 members from 64 countries.

The Eurasian Dry Grassland Group (EDGG) is a network of researchers and conservationists interested in any type of Palaearctic natural and semi-natural grasslands. It is an official subgroup of IAVS (http://www.iavs.org) but one can join our group without being an IAVS member. We live from the activities of our members. Everybody can join the EDGG without any fee or other obligation.

The EDGG covers all aspects related to grasslands, in particular: plants - animals - fungi - microbia - soils - taxonomy - phylogeography - ecophysiology - population biology - species' interactions - vegetation ecology - syntaxonomy - landscape ecology - biodiversity - land use history - agriculture - nature conservation - restoration - environmental legislation - environmental education.

\section{EDGG Executive Committee and responsibilities of its members}

Didem Ambarlı, Turkey

didem.ambarli@gmail.com

Chief Editor of the Website; Deputy IAVS Representative and Treasurer; Deputy Conference Coordinator

Idoia Biurrun, Spain

idoia.biurrun@ehu.es

Membership Administrator; Deputy Chief Editor of Palaearctic Grasslands; Deputy Field Workshop Coordinator

Jürgen Dengler, Switzerland

juergen.dengler@uni-bayreuth.de

Coordinator for Special Features; Field Workshop Coordinator; Deputy Chief Editor of Palaearctic Grasslands

Anna Kuzemko, Ukraine

anyameadow.ak@gmail.com

Chief Editor of Palaearctic Grasslands; Facebook Group Administrator

\section{Péter Török, Hungary}

molinia@gmail.com

IAVS Representative and Treasurer; Deputy Coordinator for Special Features; member of the Editorial Board of Palaearctic Grasslands

\section{Stephen Venn, Finland}

stephen.venn@helsinki.fi

Secretary-General; Deputy Facebook Group Administrator; member of the Editorial Board of Palaearctic Grasslands

Michael Vrahnakis, Greece

mvrahnak@teilar.gr

Conference Coordinator

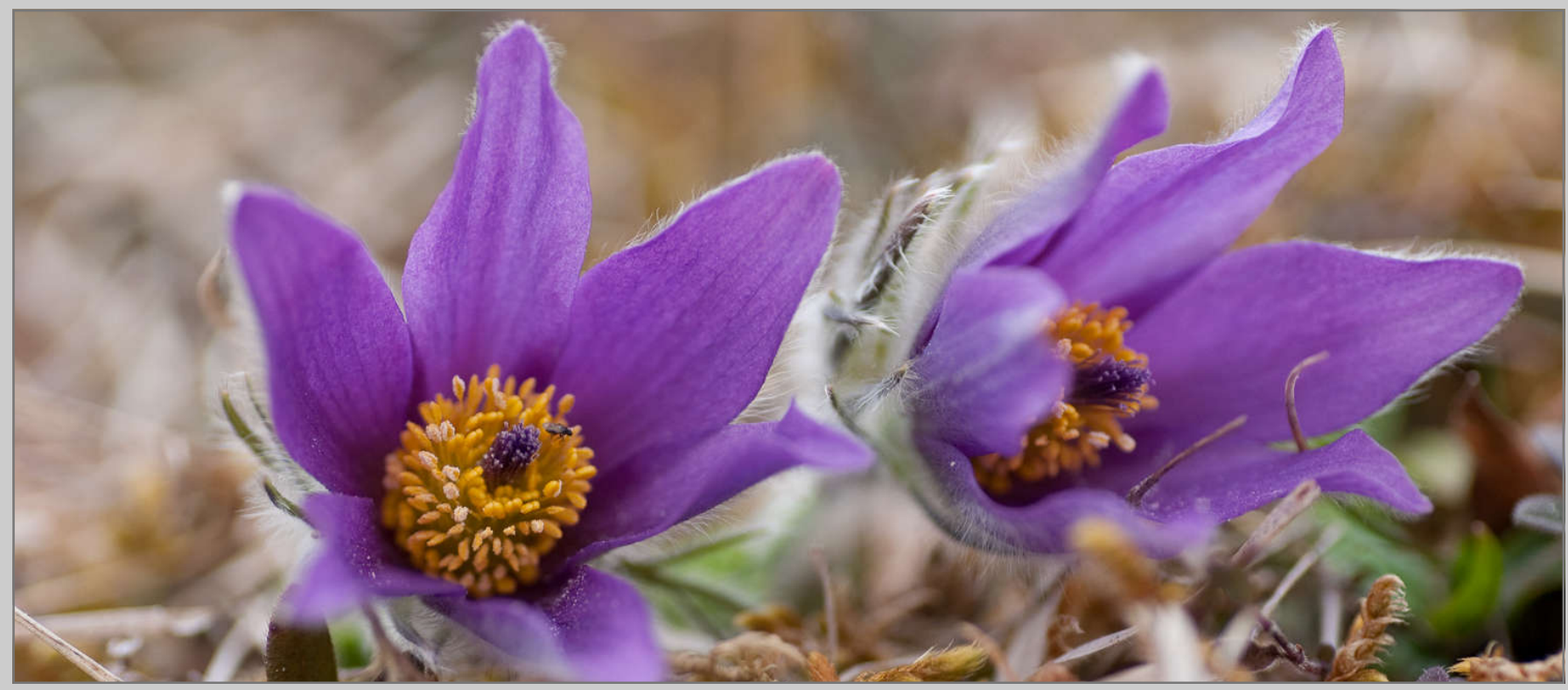

Pulsatilla vulgaris in the nature reserve "Seetalhalde-Galgenberg", Swabian Alb, Germany, a herold of pre-spring. Photo: J. Dengler. 